\title{
IDENTIFIKASI POLA STRUKTUR RUMAH TINGGAL, STUDI KASUS: ARSITEKTUR TRADISIONAL MELAYU DI KOTA PONTIANAK
}

\author{
Zairin Zain \\ Dosen pada Program Studi Arsitektur, Universitas Tanjungpura \\ E-mail: Zairin.zain@untan.ac.id \\ Rinada Shafa Alam \\ Mahasiswa pada Program Studi Arsitektur, Universitas Tanjungpura
}

\begin{abstract}
Abstrak
Bangunan - bangunan tradisional yang berbeda secara etnis menjadi saksi fisik atas pembangunan pada masa lampau yang berlandaskan adat istiadat sehingga menjadikan bangunan tradisional etnis Melayu di Kelurahan Bansir Laut Kecamatan Pontianak Tenggara memiliki ciri dan pola struktur tersendiri. Oleh karena itu, perlu dilakukan identifikasi pola struktur yang menjadi dasar konstruksi pada bangunan rumah tradisional etnis Melayu ini untuk mendapatkan perkembangan jenis karya arsitektur tanpa arsitek ini. Pengamatan penelitian ini difokuskan pada sebuah bangunan tradisional Melayu di Kelurahan Bansir Laut dengan tujuan melakukan identifikasi pola struktur. Analisis dilakukan dengan cara mendeskripsikan struktur per segmen berdasarkan grid-grid yang ditemukan pada obyek penelitian. Grid tersebut dianalisis dengan pembagian struktur bawah, tengah dan atas. Grid-grid tersebut dihitung dan dianalisis terhadap volume material struktur dan volume ruang strukturnya. Dari penelitian ini dapat disimpulkan bahwa struktur bawah menopang 7/5 dari total konstruksi struktur bawah dan struktur atas. Dengan komparasi antarastruktur tengah, bawah dan atas maka disimpulkan bahwa volume material pada grid struktur bawah di studi kasus harus lebih besar dari volume material struktur tengah. Penggunaan material struktur bawah yang terlalu besar menyebabkan keborosan struktur jika dibandingan dengan volume ruang yang dinaungi.Hal ini sebagai konsekuensi grid struktur bawah menjadi elemen yang menopang struktur tengah dan atas bangunan rumah tradisional.
\end{abstract}

Kata-kata kunci: pola struktur, rumah tradisional, komposisi

\section{IDENTIFICATION OF HOUSE STRUCTURAL PATTERN, CASE STUDY: MALAY TRADITIONAL ARCHITECTURE IN PONTIANAK CITY}

\begin{abstract}
Traditional buildings which different ethnically were physical witnesses of past development, which was based customed so this made the Malays traditional building in the Village of Sea Bansir District of Pontianak Southeast has the characteristics and the pattern of its own structure. Therefore, it is necessary to identify the pattern of the structure as base of the construction on the houses of traditional Malays to get the development of this architecture without architects. This study focused on a traditional Malay building in the Village Bansir Sea with the aim to identify the structural pattern. The analysis was performed by describing the structure per segment based on grids that were found on the object of study. The grid structure was analyzed by divide it into lower, middle and upper structure. Grids were calculated and analyzed in relation to the volume of structural material and volume of space structure. From this study it could be concluded that the structure under construction prop up 7/5 of the total bottom structure and the upper structure. By comparison between lower, middle and upper structure, it was concluded that the volume of material
\end{abstract}


at the bottom of the structure grid in the case study should be greater than the volume of the structural material of the center. The use of massive lower structural materials caused structure dissipation when compared with the volume of shaded space. This was the consequence of lower grid structure element that sustained the structure of the middle and top of traditional houses.

Keywords: Structural pattern, traditional house, composition

\section{Latar Belakang}

Menurut Mayasari dkk (2014), kebudayaan akan terus berkembang begitu juga dengan interior dan arsitektur nusantara yang dapat dilihat dari keberagaman jenis, bentuk, dan aspek materialitas lainnya dan merambah pada dimensi spiritual, psikologis, sosial, dan kultural. Bangunan - bangunan tradisional yang berbeda secara etnis menjadi saksi fisik atas pembangunan pada masa lampau yang berlandaskan adat istiadat sehingga menjadikan bangunan tradisional etnis Melayu di Kelurahan Bansir Laut Kecamatan Pontianak Tenggara memiliki ciri dan pola struktur tersendiri.

Menurut Suharjanto (2011), tradisi adalah sebuah kegiatan yang dilakukan secara terus menerus atau sebuah kebudayaan atau sebuah hasil karya yang dianggap berhasil dan memiliki legitimasi dalam kurun waktu yang cukup panjang dan bahkan sangat panjang (lama) yang diikuti oleh generasi generasi berikutnya secara turun temurun.Pembangunan rumah tradisional di Kelurahan Bansir Laut dilakukan secara tradisional sejalan dengan awal pembentukan permukiman yang berada di tepian sungai Kapuas. Bangunan tradisional Melayu memiliki karakteristik material bangunan dari kayu struktur lantai panggung, ornamen dengan motif - motif dan ukiran - ukiran tanaman.Selain itu, Penggunaan warna yang khas dengan pola ruang dalam rumah menjadi karakteristik arsitektur Melayu yang tidak lepas dari akar budaya dan adat istiadat yang dianut.

Menurut Lestari dkk (2016), bangunan rumah-rumah di tepian sungai Kapuas merupakan bangunan kayu mulai dari pondasi, lantai, rangka, sampai atap. Antara satu bagian dengan bagian lain dalam bangunan tidak dapat dipisahkan, karena satu komponen bagian bangunan menjadi komponen bagian lain dari bangunan.Balok penghubung antar pondasi menjadi bagian dari konstruksi lantai, sebagai tumpuan balok lantai.Balok lantai sekaligus sebagai pengaku bagian rangka bangunan.Balok penutup bagian paling atas dari rangka sekaligus sebagai balok tumpuan untuk rangka atap.Keseluruhan bagian bangunan menjadi kesatuan secara sistem, yang saling terkait dan berhubungan. Oleh karena itu, perlu dilakukan identifikasi pola struktur yang menjadi dasar konstruksi pada bangunan rumah tradisional etnis Melayu di Kelurahan Bansir Laut Kecamatan Pontianak Tenggara Kota Pontianak untuk mendapatkan perkembangan jenis karya arsitekturtanpa arsitek ini.

\section{Tinjauan Pustaka}

Menurut Usop (2011), kearifan lokal (local wisdom) merupakan gagasan konseptual yang hidup didalam masyarakat, tumbuh dan berkembang secara terus menerus dalam kesadaran bermasyarakat dan telah menjadi tradisi-fisik-budaya, dan secara turun temurun menjadi dasar dalam membentuk bangunan dan lingkungannya. Kearifan lokal merupakan sebuah nilai luhur kebudayaan yang dimiliki masyarakatuntuk selalu menghargai alam dan lingkungannya. Menurut Manurung (2014), Arsitektur tradisional di tanah air telah dirancang dibangun dan dihuni dengan konsep berkelanjutan. Penggunaan material alam yang tidak melalui proses pabrikasi yang tidak ramah lingkungan, pengawetan material seperti bambu yang dilakukan secara alami, merupakan satu contoh pendekatan keberlanjutan yang digunakan. Rahmansah dan Rauf (2014) mengatakan, arsitektur tradisional adalah kebudayaan fisik yang dalam konteks tradisional merupakan bentuk ungkapan yang berkaitan erat dengan kepribadian masyarakatnya. Ungkapan fisik sangat dipengaruhi oleh faktor sosio-kultural dan lingkungan dilokasi kebudayaan tersebut tumbuh dan berkembang, 
sehingga perbedaan latar sosio-kultural dan lingkungan mempengaruhi ungkapan dalam arsitekturalnya.

Menurut Suharjanto (2011: 601), Arsitektur vernakular adalah istilah yang digunakan untuk mengkategorikan metode kontruksi yang menggunakan sumber daya orisinal lokal untuk memenuhi kebutuhan lokal. Arsitektur vernakular berkembang setiap waktu untuk merefleksikan lingkungan, budaya, dan sejarah dari daerah dimana karya arsitektur tersebut muncul dan berada atau eksis. Menurut Manurung (2014), dari sisi struktur dan konstruksi, dapat kita lihat contoh arsitektur tradisional yang telah mempertimbangkan sistem struktur yang berkelanjutan. Secara konstruksi, sistem struktur ini tidak melukai bumi sebagaimana sistem struktur tiang pancang pada bangunan modern.Struktur bangunan diletakkan di atas pondasi umpak dan mengurangi dampak yang ditimbulkan pada struktur tanah.Sistem struktur yang merespon gempa, kondisi tanah, dan faktor alam lainnya, menunjukkan pendekatan yang kontekstual dan responsif. Demikian halnya dalam upaya menciptakan kenyamanan di dalam bangunan, desain yang mengoptimalkan masuknya cahaya alami dan penghawaan alami menunjukkan pendekatan desain hemat energi dan penggunaan energi terbarukan.

\section{Metodologi Penelitian}

Penelitian dilaksanakan di Kelurahan Bansir Laut, Kecamatan Pontianak Tenggara, Kota Pontianak yang berada di tepi sungai Kapuas.Pengamatan penelitian ini difokuskan pada sebuah bangunan tradisional Melayu di Kelurahan Bansir Laut dengan tujuan melakukan identifikasi pola struktur. Kelurahan Bansir Laut saat ini masih banyak memiliki rumah tradisional akibat pergerakan permukiman dan perdagangan saat dulu. Secara umum pemilihan lokasi penelitian memiliki syarat yaitu bangunan rumah tinggal dengan struktur dan konstruksi tradisional seperti penggunaan lantai panggung, penggunaan bahan bangunan dan lamanya umur bangunan. Obyek penelitian berada di tepian sungai Kapuas Kelurahan Bansir Laut yaitu rumah tradisional Melayu yang terletak di Jl. Imam Bonjol Gg. Bansir 2 Kel.Bansir Laut Kecamatan Pontianak Tenggara Kota Pontianak.Teknik dalam menganalisis data yaitu dengan cara deskriptif dan pendekatan metode kuantitatif dengan cara melakukan perhitungan untuk mengkaji fakta dan fenomena terhadap objek penelitian.

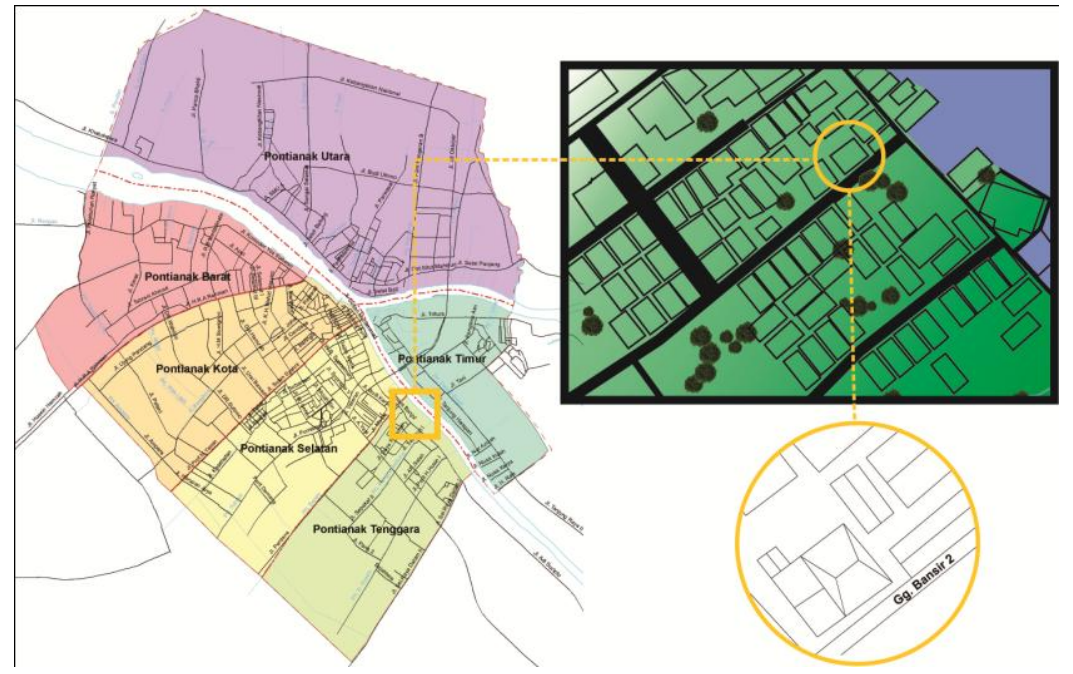

Gambar 1. Lokasi obyek studi kasus di Kelurahan Bansir Laut, Kecamatan Pontianak Tenggara

Sumber: Penulis, 2016 


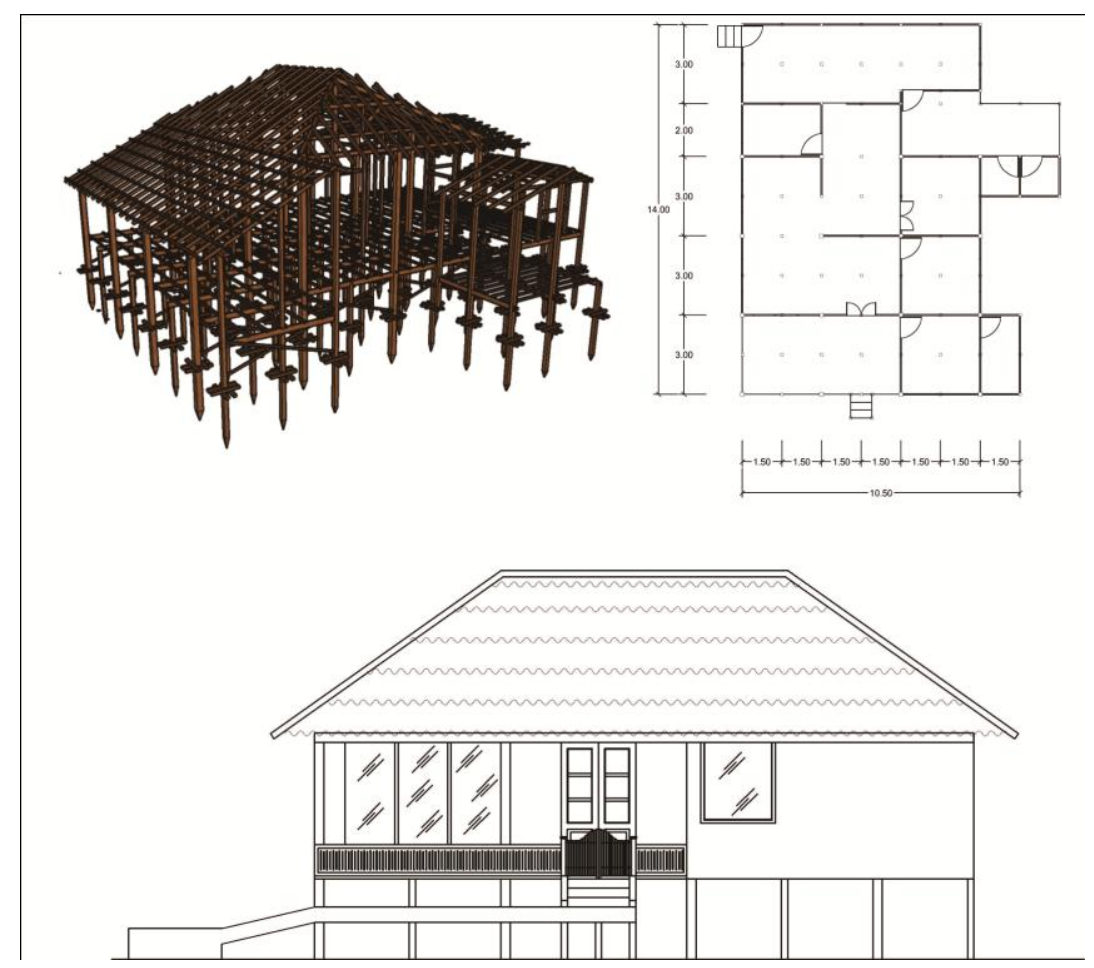

Gambar 2. Ilustrasi Rumah Tradisional Melayu di Kelurahan Bansir Laut, Kecamatan Pontianak Tenggara

Sumber: Penulis, 2016

Analisis dilakukan dengan cara mendeskripsikan struktur per segmen berdasarkan grid-grid yang ditemukan pada obyek penelitian. Grid tersebut dianalisis dengan pembagian struktur bawah, tengah dan atas. Sebagai analogi, dalam satu bangunan membentuk ruang yang selanjutnya disebut segmen.Setiap segmen akan dibatasi oleh dinding yang terbentuk dari tiang-tiang kayu dengan jarak tertentu dan selanjutnya disebut grid. Setiap obyek penelitian akan dibagi menjadi beberapa segmen dengan beberapa grid didalamnya. Oleh karena itu, grid-grid tersebut dihitung dan dianalisis terhadap volume material struktur dan volume ruang strukturnya. Jika segmen 1 sudah selesai dilakukan analisis, kemudian akan dibandingkan dengan grid - grid di segmen 2 dan begitu seterusnya.
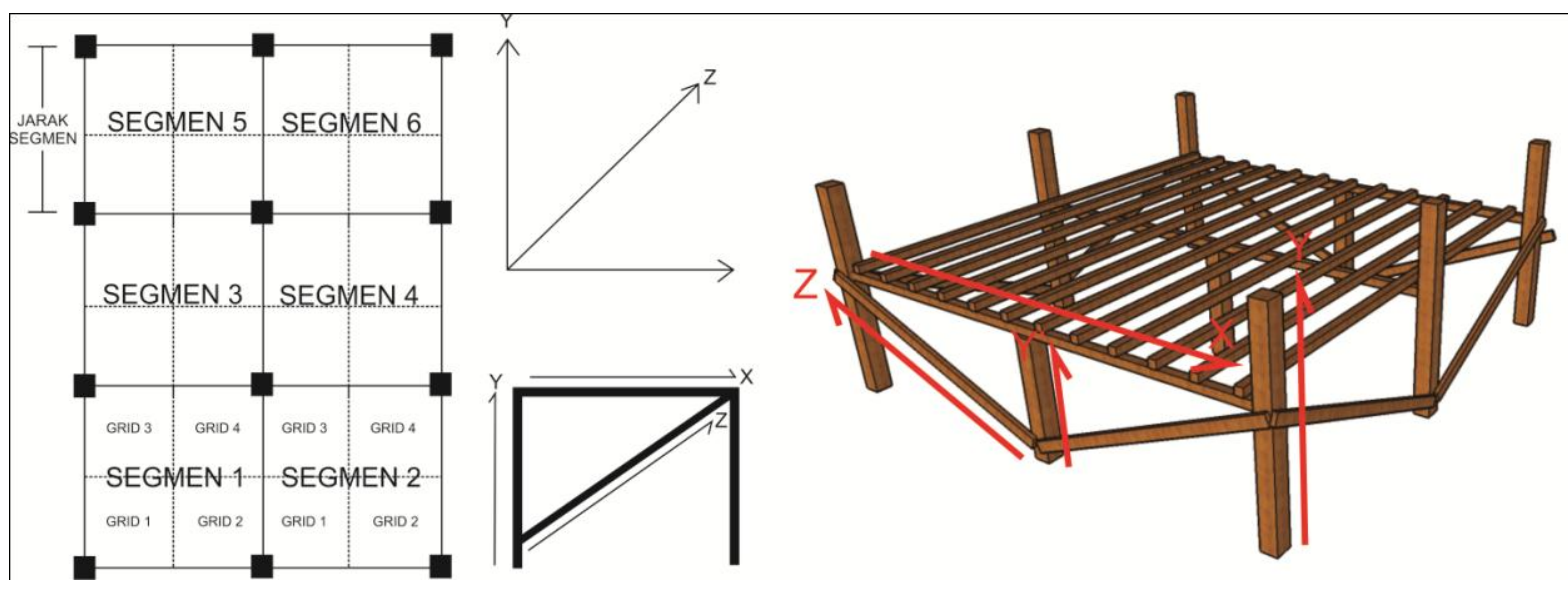

Gambar 3. Ilustrasi segmen dalam obyek penelitian untuk analisis pola struktur rumah tradisional Sumber: Penulis, 2016 
Tabel 1. Penjelasan Penamaan Sumbu obyek penelitian untuk analisis pola struktur rumah tradisional

\begin{tabular}{|c|c|c|c|c|c|c|}
\hline \multicolumn{7}{|c|}{ SUMBU } \\
\hline $\mathrm{NO}$ & \multicolumn{2}{|r|}{$X$} & \multicolumn{2}{|c|}{$\mathrm{Y}$} & \multicolumn{2}{|r|}{$Z$} \\
\hline 1 & $\mathrm{X} 1$ & Balok Keep & \multirow{2}{*}{$\mathrm{Y} 1$} & \multirow{2}{*}{$\begin{array}{c}\text { Tiang Tongkat } \\
\text { Menerus }\end{array}$} & $\mathrm{Z1}$ & Selempang \\
\hline 2 & $\mathrm{X} 2$ & Balok Anak & & & $\mathrm{Z} 2$ & Penopang \\
\hline 3 & $\mathrm{X} 3$ & Palang Jendela & Y1' & Tiang Tongkat & $\mathrm{Z3}$ & Batang Sokong \\
\hline 4 & $\mathrm{X} 4$ & Balok Tembok Lt.1 & $\mathrm{Y} 2$ & Kolom & $\mathrm{Z4}$ & Kaki Kuda - Kuda \\
\hline 5 & $\mathrm{X} 5$ & Balok Anak Lt.1 & $\mathrm{Y}^{\prime}$ & Kolom Praktis & $\mathrm{Z5}$ & Gording \\
\hline 6 & $\mathrm{X} 6$ & Balok Tarik & \multirow{3}{*}{ Y3 } & \multirow{3}{*}{ Tiang Gantung } & Z6 & Kasau \\
\hline 7 & $\mathrm{X} 7$ & Balok Tembok Lt.1 & & & $\mathrm{Z7}$ & Reng \\
\hline 8 & $\mathrm{X} 8$ & Balok Bubungan & & & $\mathrm{Z8}$ & Sokong Atap \\
\hline
\end{tabular}

Sumber: Penulis, 2016

\section{Hasil}

Obyek kasus merupakan merupakan rumah tinggal turun temurun berusia 120 tahun dengan ukuran bangunan 10,50m x 14m dan saat ini ditempati oleh Ibu Ramlah. Berdasarkan deskripsi, maka studi kasus dapat digolongkan menjadi pola struktur berdasarkan grid dan deskripsi per segmen. Struktur bawah pada studi kasus terbagi menjadi 3 segmen. Pada segmen 1 terdiri dari 11 grid yang berukuran $3 \mathrm{~m} \times 3 \mathrm{~m}$ dan $3 \mathrm{~m} \times 1.5 \mathrm{~m}$. Segmen 2 terdiri dari 4 grid berukuran $2 \mathrm{~m} \times 1,5 \mathrm{~m}$ dan pada segmen 3 terdiri dari tiga grid berukuran 1,5m x 1,5m. Struktur tengah pada Studi Kasus dibagi menjadi 5 segmen. Jarak antar grid per segmen terdiri dari $3 \mathrm{~m}$ x 3m, $2 \mathrm{~m}$ x $3 \mathrm{~m}$ dan 1,5m x 1,5m. Pada struktur tengah, penjelasan terbagi menjadi X3 dan Y2 serta Y2'. Struktur atas pada Studi Kasus memiliki 5 jenis atas yang berbeda sehingga memiliki 5 segmen dan dalam satu segmen hanya terdapat satu atap sebagai grid yang satu kesatuan.

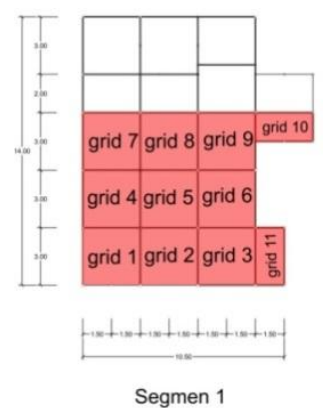

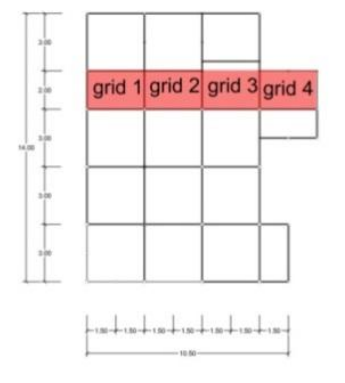

Segmen 2

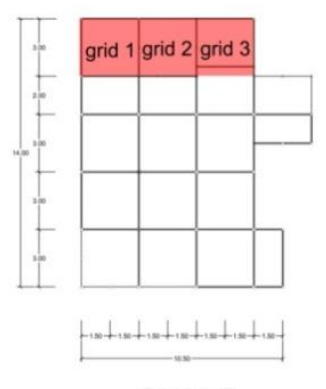

Segmen 3

a. Struktur Bawah

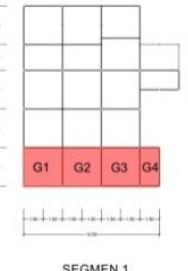

SEGMEN 1

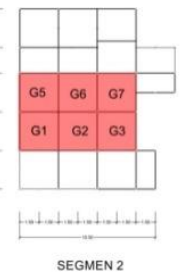

$$
\text { b. }
$$

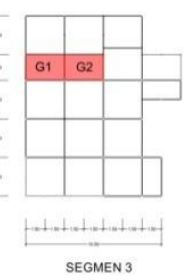

Struktur Tengah
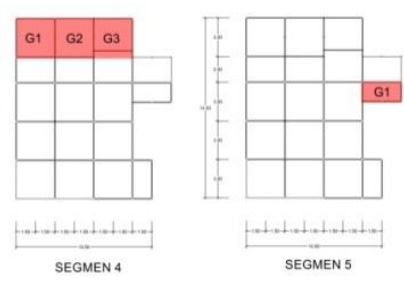

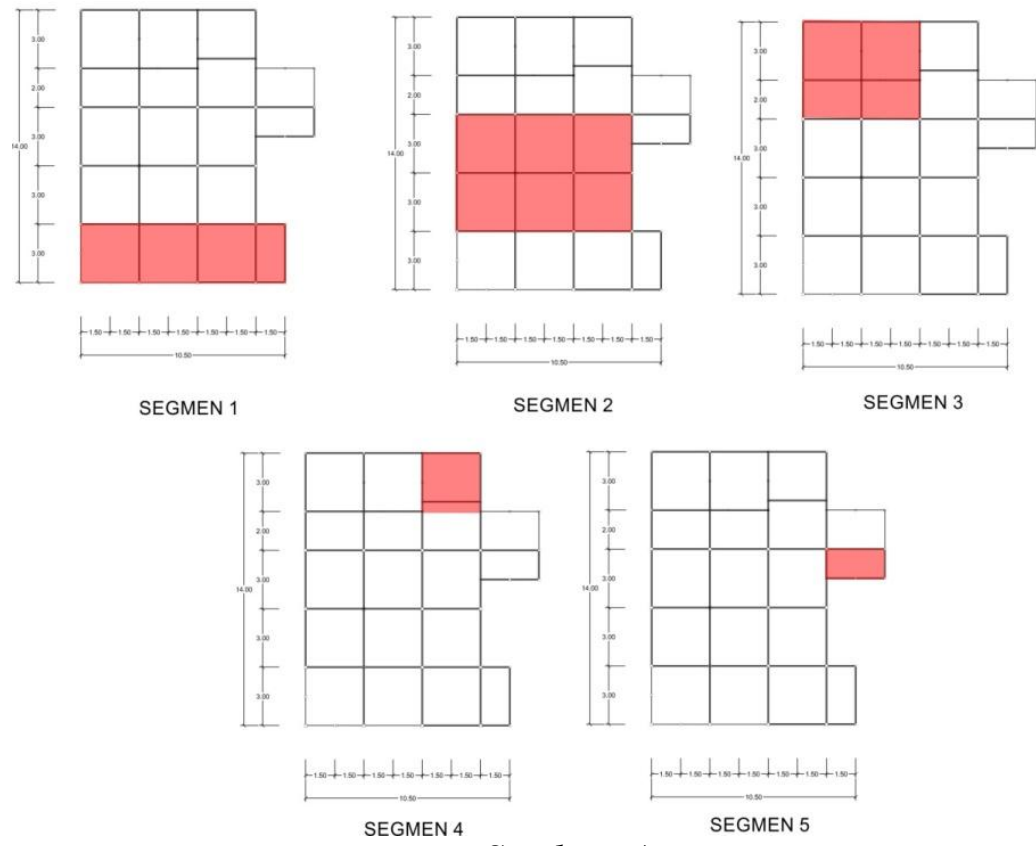

c. Struktur Atas

Gambar 4. Pembagian Segmen dan Grid Rumah Tradisional Melayu di Kelurahan Bansir Laut, Kecamatan Pontianak Tenggara

Sumber: Penulis, 2016

\section{Struktur Bawah}

Pada segmen 1, grid 1 - 3 mempunyai bentuk dan ukuran grid yang sama yaitu jarak antar Y1 dan Y1 lainnya yaitu $3 \mathrm{~m}$ dengan jarak $\mathrm{Y} 1$ dan $\mathrm{Y} 1$ ' adalah $1,5 \mathrm{~m}$. Ukuran pada $\mathrm{Y} 1$ adalah $15 / 15 \mathrm{~cm}$ dengan jarak $3 \mathrm{~m} \times 3 \mathrm{~m}$. Tinggi Y1 pada grid $1-3$ yaitu $1,30 \mathrm{~m}$. X1 pada grid $1-3$ berukuran $4 / 17 \mathrm{~cm}$ dan $\mathrm{X} 2$ yang berada di atas $\mathrm{X} 1$ berukuran $5 / 5 \mathrm{~cm}$. Z1 pada grid $1-3$ memiliki material berukuran $4 / 4 \mathrm{~cm}$ dengan kemiringan $35^{\circ}$. Grid $4-9$ memiliki bentuk dan ukuran grid yang sama yaitu dengan jarak antar Y1 adalah 3m x 3m dan jarak antar Y1 dengan Y1' adalah 1,5m. Y1 memiliki ketinggian yaitu 1,50m dengan ukuran Y1 yaitu $15 / 15 \mathrm{~cm}$ dan ukuran $Y 1$ ' adalah $10 / 10 \mathrm{~cm}$. Pada X1 memiliki ukuran sebesar $4 / 17 \mathrm{~cm}$ dengan X2 yang berada diatasnya yaitu berukuran $5 / 5 \mathrm{~cm}$. Ukuran pada $\mathrm{Z} 1$ pada grid $4-9$ yaitu $4 / 4 \mathrm{~cm}$ dengan kemiringan $35^{\circ}$. Grid 10 memiliki ukuran grid sebesar $1,5 \mathrm{~m}$ x $3 \mathrm{~m}$ dengan ukuran Y1 yaitu 10/10cm. Ukuran X1 yaitu 4/17 cm dan ukuran X2 sebesar $5 / 5 \mathrm{~cm}$. Pada Z1, material berukuran $4 / 4 \mathrm{~cm}$ dengan kemiringan $35^{\circ}$. Pada Grid 11, grid memiliki ukuran sebesar $1,5 \mathrm{~m}$ x 1,5m dengan dimensi material $Y 1$ dan $Y 1$ ' yaitu $10 / 10 \mathrm{~cm}$ dan X1 berukuran $4 / 17 \mathrm{~cm}$ serta X2 yang berukuran $5 / 5 \mathrm{~cm}$. 


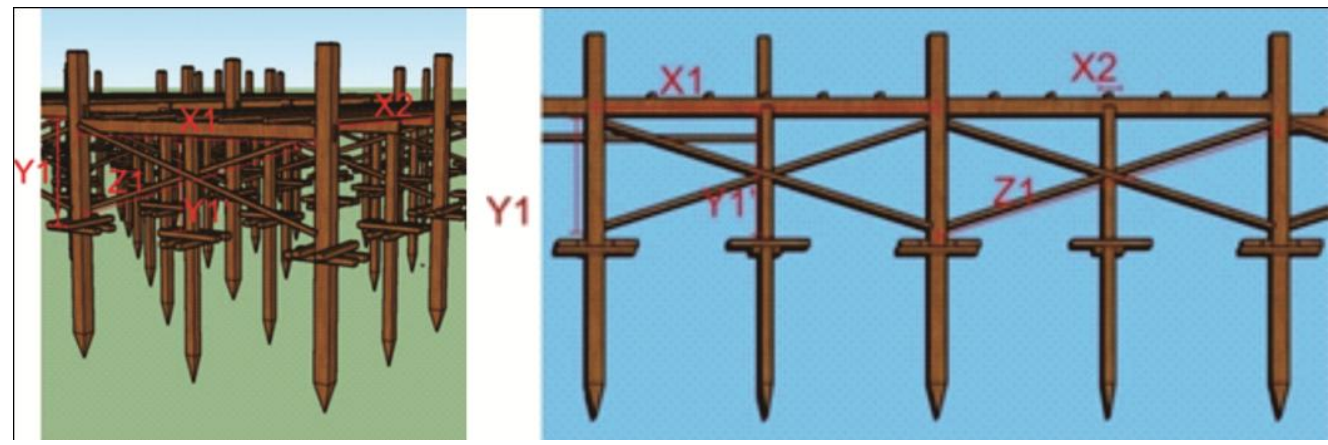

a. Segmen 1 Grid $1-3$

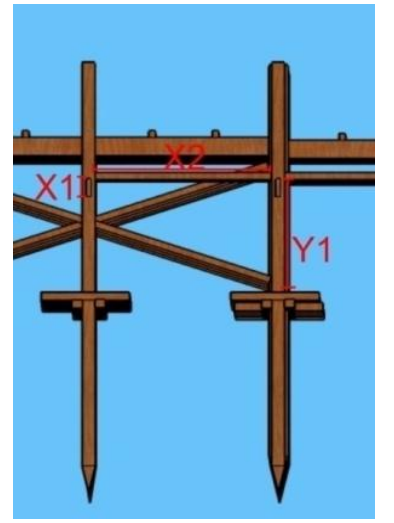

b. Segmen 1 Grid 4-9

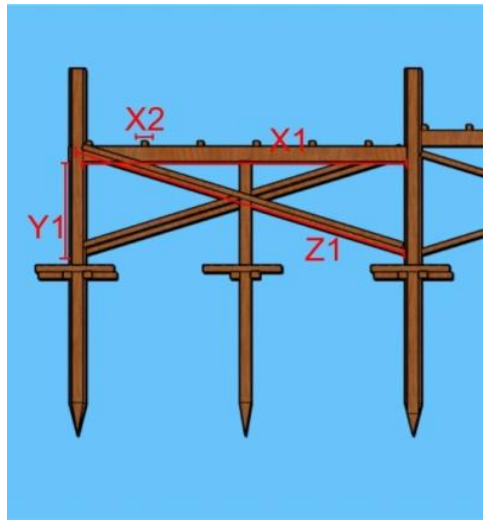

c. Segmen 1 Grid $10-11$

Gambar 5. Segmen 1 pada struktur bawah Rumah Tradisional Melayu di Kelurahan Bansir Laut, Kecamatan Pontianak Tenggara

Sumber: Penulis, 2016

Pada segmen 1, grid 1 hingga 3 memiliki bentuk ruang struktur dan dimensi material yang sama. Dengan jarak antar grid pada segmen yaitu $2 \mathrm{~m}$ x $3 \mathrm{~m}$ dan jarak antar material $\mathrm{Y} 1 \mathrm{ke} \mathrm{Y} 1$ ' yaitu 1,5m. Ukuran material Y1 pada segmen 2 di grid $1-3$ yaitu sebesar $15 / 15 \mathrm{~cm}$ dengan ukuran $\mathrm{Y} 1$ ' adalah 10/10cm. Tinggi Y1 dan Y1' pada grid $1-3$ di segmen 2 adalah 1,50m dengan material X1 berukuran $4 / 17 \mathrm{~cm}$ dan X2 berukuran $5 / 5 \mathrm{~cm}$. Grid 4 memiliki Y1 dengan ukuran 10/10cm dan jarak antar Y1 yaitu 1,50m. Pada grid 4, Y1 mempunyai ketinggian 1 meter dengan ukuran X1 yaitu 4/17 cm dan ukuran X2 adalah 5/5cm dan berjarak 0,5m. Pada Segmen 3, ukuran grid yaitu 1,5m x $1,5 \mathrm{~m}$ dengan ukuran material $\mathrm{Y} 1$ yaitu $10 / 10 \mathrm{~cm}$. Tinggi $\mathrm{Y} 1$ yaitu $1,50 \mathrm{~m}$ yang diatasnya terdapat $\mathrm{X} 1$ berukuran $4 / 17 \mathrm{~cm}$ dan X2 berukuran $5 / 5 \mathrm{~cm}$ dengan jarak antar X2 yaitu 0,5m x 0,5m. Bagian pada segmen 3 merupakan bagian dari dapur dan pelataran belakang yang terdapat pada Studi Kasus.

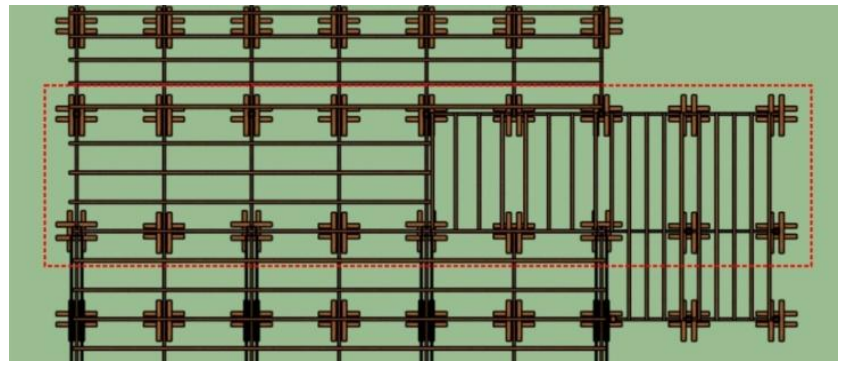

a. Segmen 2 

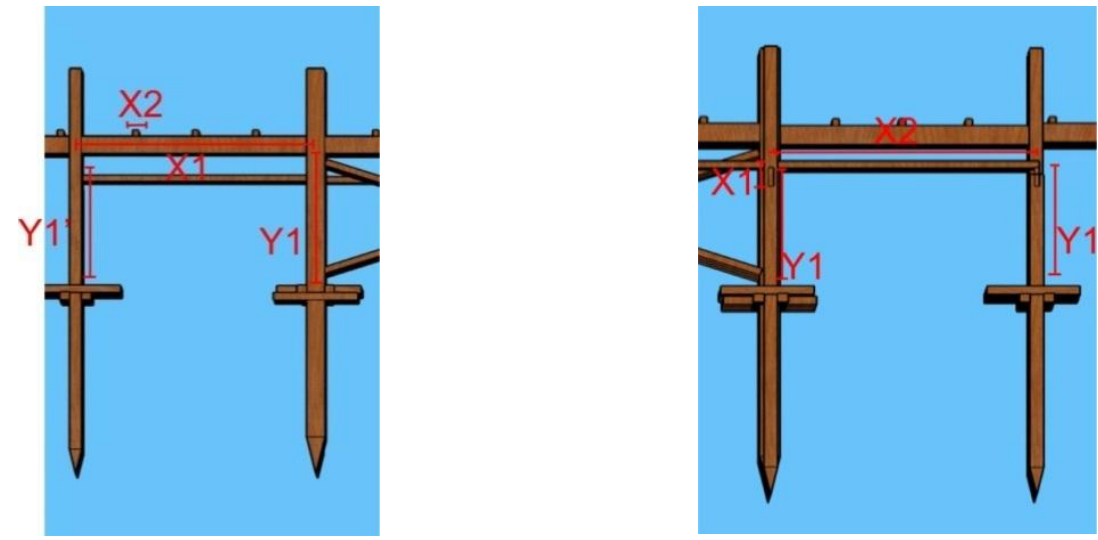

b. Segmen 2 Grid $1-3$ dan Grid 4

Gambar 6. Segmen 2 pada struktur bawah Rumah Tradisional Melayu di Kelurahan Bansir Laut, Kecamatan Pontianak Tenggara

Sumber : Penulis, 2016

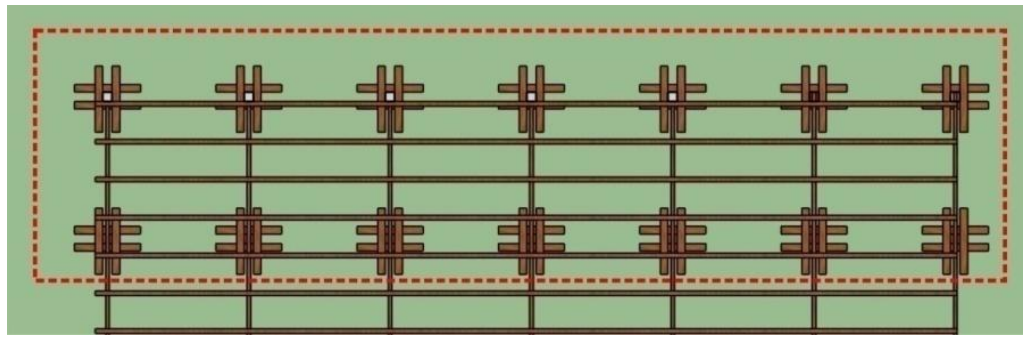

a. Segmen 3

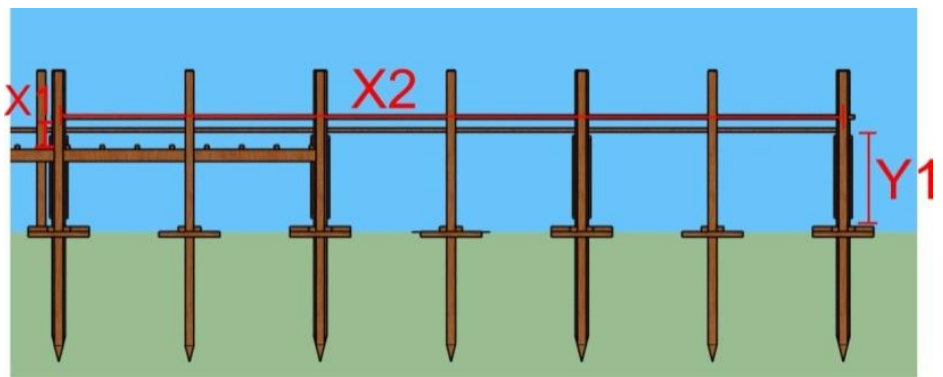

b. Segmen 3 Grid 1 - 6

Gambar 7. Segmen 3 pada struktur bawah Rumah Tradisional Melayu di Kelurahan Bansir Laut, Kecamatan Pontianak Tenggara

Sumber: Penulis, 2016

\section{Struktur Tengah}

Segmen 1 terdiri dari dari empat grid dengan ukuran grid $3 \mathrm{~m}$ x $3 \mathrm{~m}$ jarak antar material struktur Y2 dan Y2' menyesuaikan dengan letak jendela serta pintu. Pada Segmen 1 Grid 1 yang berukuran $3 \mathrm{~m} \times 3 \mathrm{~m}$, ukuran $\mathrm{Y} 2$ yaitu $15 / 15 \mathrm{~cm}$ dan ukuran $Y 2$ ' yaitu $7 / 7 \mathrm{~cm}$. Di grid 1 , terdapat jendela sehingga jarak dari Y2 ke Y2' sebesar 30cm dan kemudian jendela sebanyak tiga buah tersebut mempunyai jarak antar Y2' sebesar $80 \mathrm{~cm}$. Ukuran X3 pada grid 1 yaitu $7 / 7 \mathrm{~cm}$ dengan jarak antar X3 yaitu $2 \mathrm{~m}$. Pada segmen 1 Grid 2 terdapat pintu utama pada area memanjang dengan jarak antar Y2' yaitu 1,20m dan ketinggian X3 yaitu 2,3m diatas X2. Diatas X3 terdapat ventilasi dengan dengan jarak antar material X3 yaitu 0,4m. Ukuran material struktur X3 dan Y2 serta Y2' sama dengan ukuran material struktur di grid 1. Pada segmen 1 Grid 3 terdapat pintu pada area melintang dengan jarak antara Y2 dan Y2' yaitu 0,9m dan terdapat X3 diantara Y2 dan Y2'. Grid 3 merupakan ruang kamar 
yang disewakan sebagai kamar kost. Segmen 1 Grid 4 merupakan tambahan untuk memenuhi fungsi pada grid 3 sebagai tempat kost. Pada grid 4, ukuran material Y2 sebesar 7/7cm dengan jarak antara Y2 pada area memanjang yaitu 1,50m dan pada area melintang yaitu $3 \mathrm{~m}$.

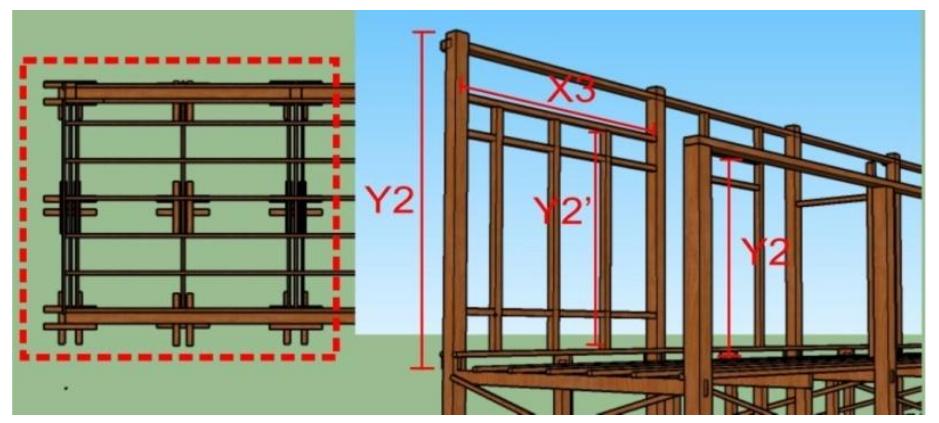

a. Segmen 1 Grid 1
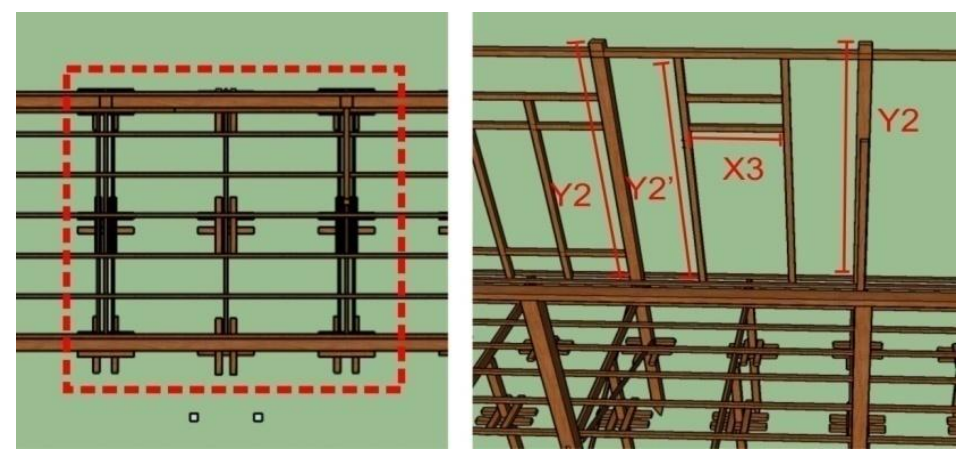

b. Segmen 1 Grid 2
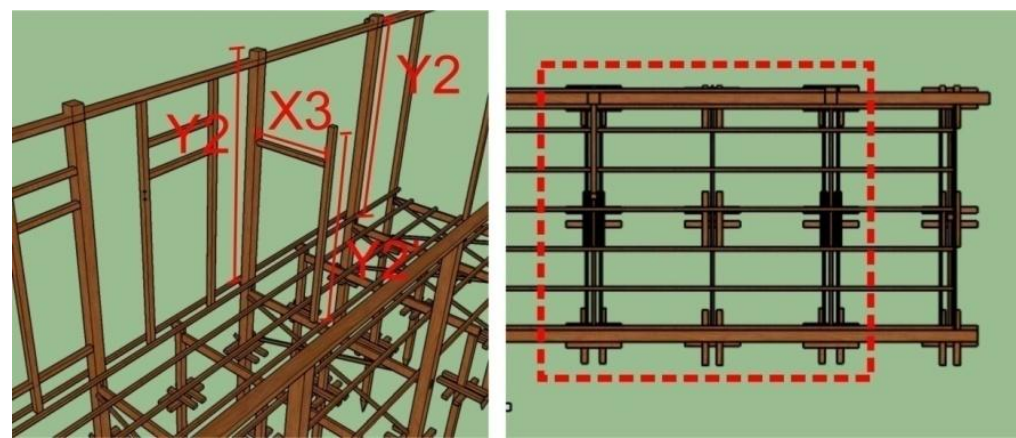

c. Segmen 1 Grid 3

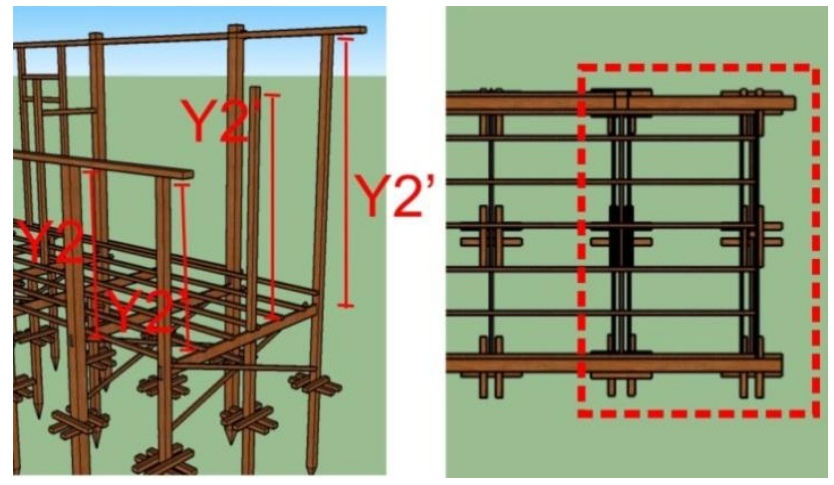

\section{d. Segmen 1 Grid 4}

Gambar 8. Segmen 1 pada Struktur Tengah Rumah Tradisional Melayu di Kelurahan Bansir Laut Sumber: Penulis, 2016 
Segmen 2 terdiri dari enam grid berukuran $3 \mathrm{~m}$ x 3m. Pada Segmen 2 Grid 1 yang terhubung langsung dengan grid 1 di segmen 1, jarak antar material struktur Y2 dan Y2 yaitu $3 \mathrm{~m}$. Antara Y2 pada area melintang terdapat Y2' dengan ukuran $7 / 7 \mathrm{~cm}$ dan jarak antar Y2' yaitu $1,20 \mathrm{~m}$. Diantara Y2' tersebut terdapat X3 dengan ukuran 7/7cm dan jarak antar X3 yaitu 1,5m. Pada segmen 2 Grid 2 yang berbatasan dengan grid 2 pada segmen 1 dan terhubung melalui pintu masuk utama memiliki ukuran ruang grid struktur sebesar $3 \mathrm{~m}$ x 3m dengan dimensi material Y2 sebesar $15 / 15 \mathrm{~cm}$ dan jarak antar Y2 dan Y2' yaitu 1,50m dan ukuran Y2' yaitu sebesar 7/7cm. Segmen 2 Grid 3 merupakan area kamar tidur dengan jarak Y2 dan Y2' yaitu 1,5m dan antar Y2 yaitu $3 \mathrm{~m}$ x 3m. Pada X3 yang berukuran $7 / 7 \mathrm{~cm}$ terletak di atas X2 dengan ketinggian 2,25m. Segmen 2 Grid 4 merupakan grid yang bersebalahan dengan grid 1 dan memiliki ketinggian dengan ukuran material struktur yang sama dan berfungsi sebagai ruang tamu atau ruang transisi antara ruang keluarga pada grid 5. Segmen 2 Grid 5 merupakan ruang keluarga dengan ukuran material Y2 yaitu $15 / 15 \mathrm{~cm}$ dan Y2' sebesar $7 / 7 \mathrm{~cm}$. Bagian pada grid 6 memiliki jendela yang langsung terhubung ke pelataran belakang dengan jarak antar X3 yaitu $1,5 \mathrm{~m}$ dan ukuran material $\mathrm{X} 3$ yaitu $7 / 7 \mathrm{~cm}$.
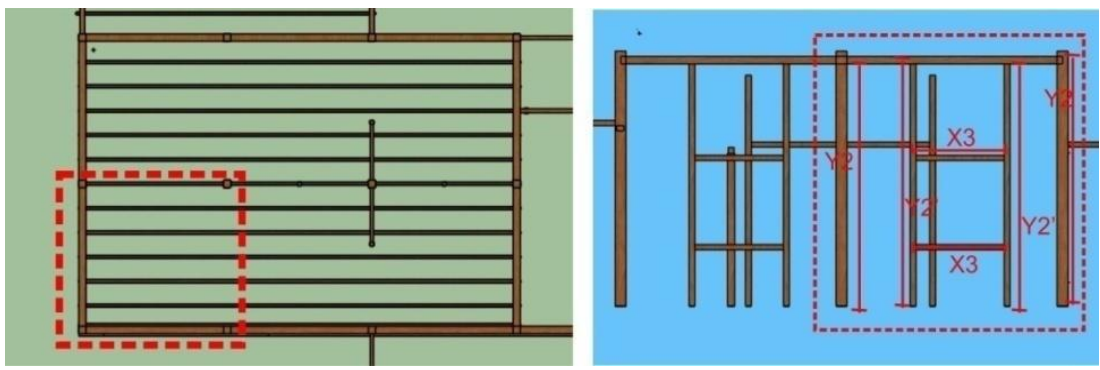

a. Segmen 2 Grid 1
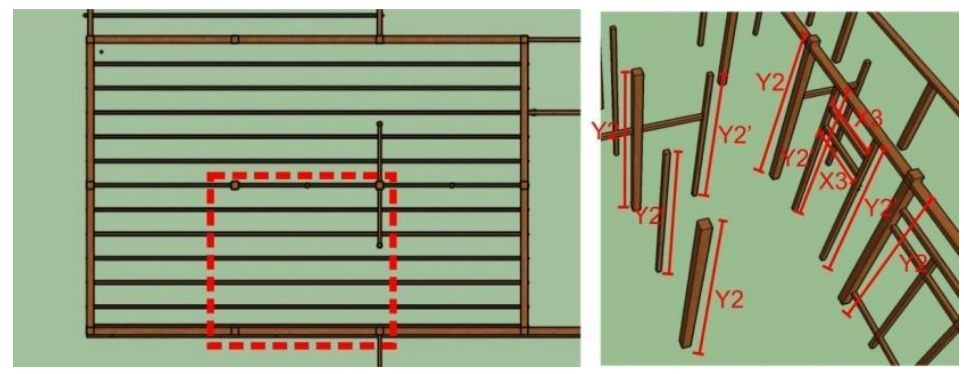

b. Segmen 2 Grid 2
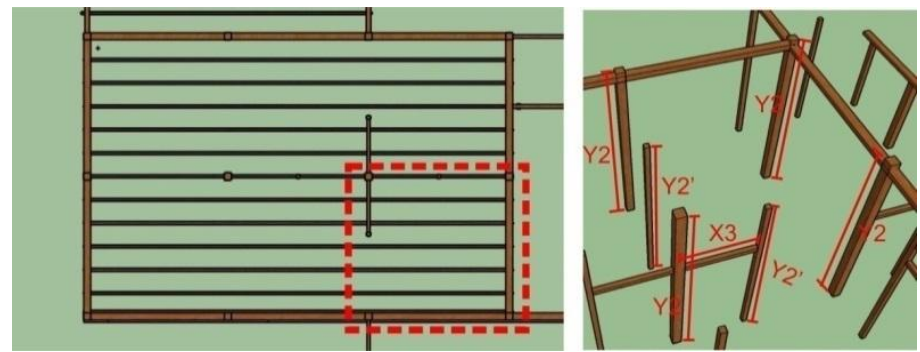

c. Segmen 2 Grid 3 

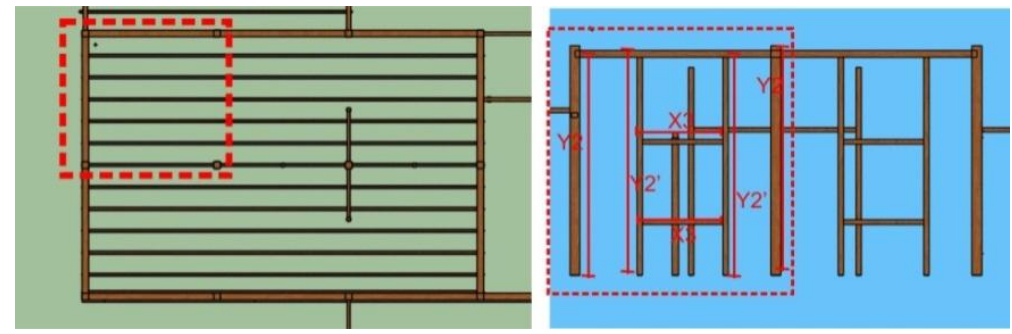

d. Segmen 2 Grid 4
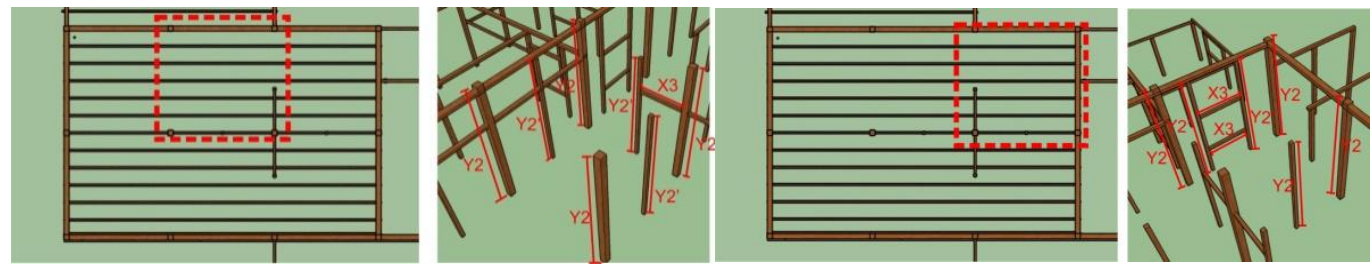

e. Segmen 2 Grid 5 dan 6

Gambar 9. Segmen 2 pada Struktur Tengah Rumah Tradisional Melayu di Kelurahan Bansir Laut Sumber: Penulis, 2016

Segmen 3 terdiri dari 2 grid berukuran $3 \mathrm{~m} \times 2 \mathrm{~m}$ dengan ukuran material Y2 yaitu $10 / 10 \mathrm{~cm}$. Ukuran Y2' sebesar $7 / 7 \mathrm{~cm}$ dengan jarak material struktur antara Y2 dan Y2' pada area melintang yaitu $1,10 \mathrm{~m}$ yang diantaranya terdapat $\mathrm{X} 3$ dengan ukuran $7 / 7 \mathrm{~cm}$ dan jarak antar $\mathrm{X} 3$ yaitu $1,2 \mathrm{~m}$.

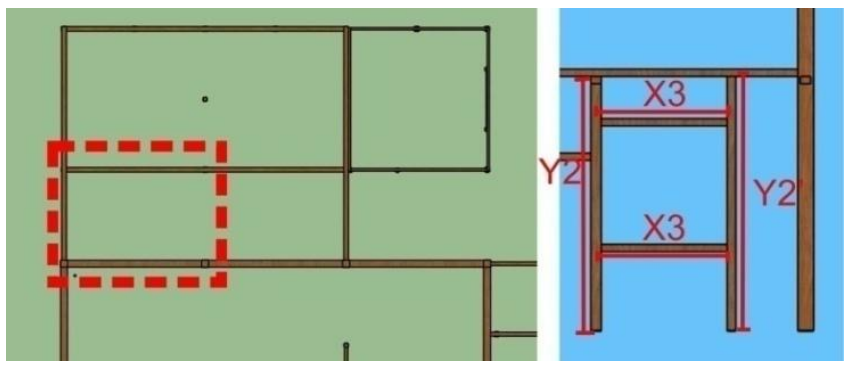

Gambar 10. Segmen 3 Grid 1 dan 2 pada Struktur Tengah Rumah Tradisional Melayu di Kelurahan Bansir Laut

Sumber: Penulis, 2016

Segmen 4 memiliki 3 grid berukuran $3 \mathrm{~m}$ x 3m. Pada Segmen 4 Grid 1 terdapt pintu masuk ke dapur dengan ukuran Y2' yaitu 7/7cm dan jarak antar Y2 dan Y2' yaitu 0.9m. Diantara Y2' dan Y2 terdapat X3 setinggi 1,8m dari X2 dengan ukuran $7 / 7 \mathrm{~cm}$. Pada Segmen 4 Grid 2 yang memiliki kesamaan dengan segmen 2 grid 5 memiliki bentuk yang sama namun berbeda ukuran. Y2 berukuran 10/10cm dan Y2' berukuran 7/7cm. Pada Grid 3 segmen 4, memiliki ukuran ruang dan penampang material struktur yang sama dengan grid 4 namun pada area melintang terdapat X3 dengan jarak antar penampangsebesar $0,8 \mathrm{~m}$.

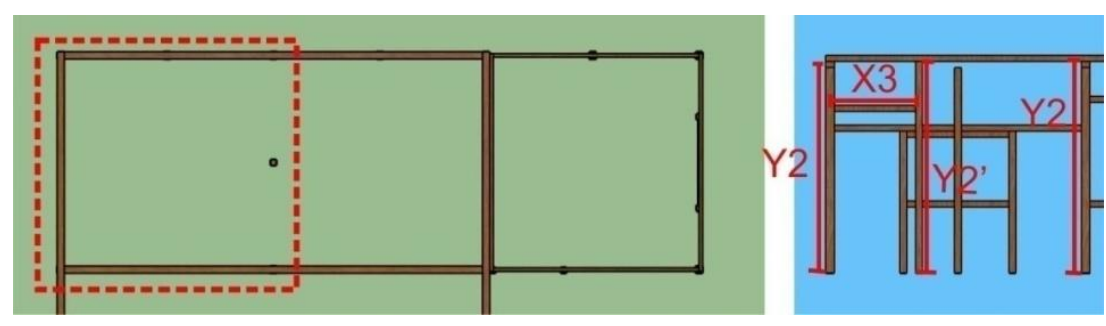

a. Segmen 4 Grid 1 


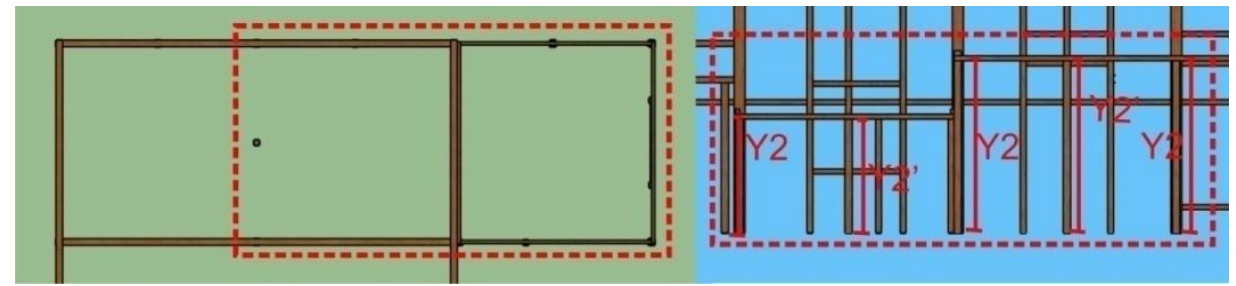

b. Segmen 4 Grid 2 dan 3

Gambar 11. Segmen 4 pada Struktur TengahRumah Tradisional Melayu di Kelurahan Bansir Laut Sumber : Penulis, 2016

Segmen 5 adalah ruang struktur tambahan yang berfungsi sebagai WC/Kamar mandi didalamnya terdapat dua buah grid berukuran $10 / 10 \mathrm{~cm}$ untuk Y2 dan memiliki jarak antar Y2 yaitu $1,5 \mathrm{~m} \times 1,5 \mathrm{~m}$.

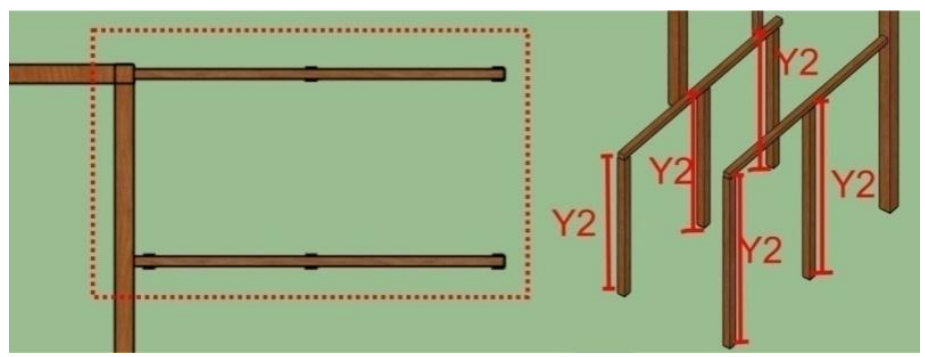

Gambar 12. Segmen 5 pada Struktur Tengah Rumah Tradisional Melayu di Kelurahan Bansir Laut Sumber : Penulis, 2016

\section{Struktur Atas}

Segmen 1 merupakan segmen dengan ruang struktur atas berupa atap setengah pelana yang berfungsi menutup area teras pada studi kasus. Pada segmen 1 struktur atap di segmen ini memiliki material struktur X7 yang berukuran $7 / 15 \mathrm{~cm}$ dan diatasnya terdapat Z6 berukuran $6 / 7 \mathrm{~cm}$ serta $\mathrm{Z} 7$ berukuran $3 / 5 \mathrm{~cm}$. Jarak antar material Z6 dan antar material Z7 yaitu sebesar $0,5 \mathrm{~m}$. Segmen ini menggunakan pelapis atap seng dengan kemiringan $25^{\circ}$.

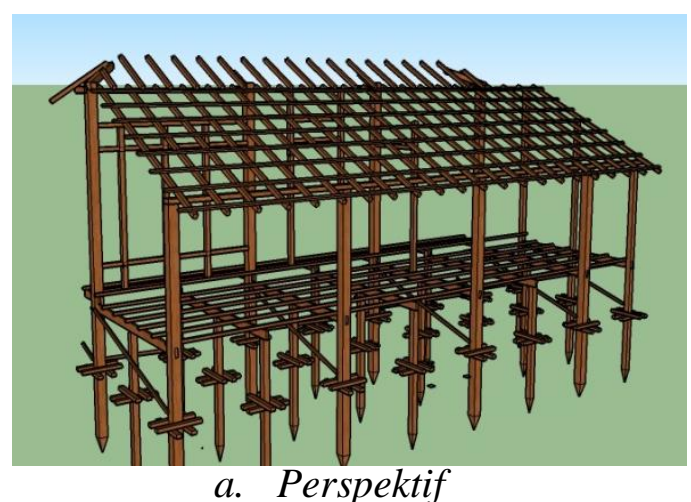




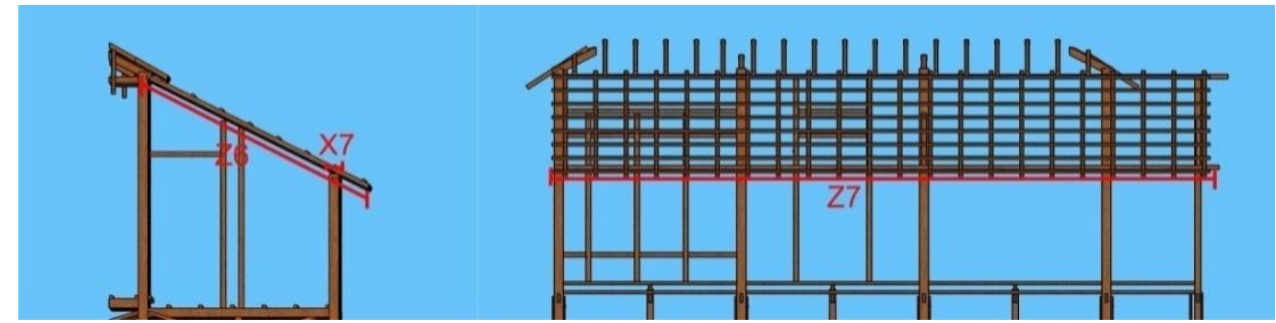

b. Segmen 1

Gambar 13. Segmen 1 pada Struktur Atas Rumah Tradisional Melayu di Kelurahan Bansir Laut Sumber: Penulis, 2016

Segmen 2 merupakan segmen struktur atap berupa atap perisai dengan ketinggian Y3 yaitu $1,75 \mathrm{~m}$ berukuran $15 / 7 \mathrm{~cm}$ dan ketinggian $\mathrm{Y} 3$ ' yaitu $1 \mathrm{~m}$ dengan dimensi sebesar $9 / 7 \mathrm{~cm}$. Jarak antar material struktur $\mathrm{Y} 3$ dan $\mathrm{Y} 3$ ' sebesar $0,9 \mathrm{~m}$ dengan $\mathrm{Y} 3$ dan $\mathrm{Y} 3$ ' yang ditopang oleh $\mathrm{X} 6$ berukuran $10 / 15 \mathrm{~cm}$. Diatas $Y 3$ dan $Y 3$ ' terdapat $\mathrm{Z} 4$ yang memiliki ukuran $8 / 8 \mathrm{~cm}$ dengan kemiringan $30^{\circ}$. Untuk menopang $Z 4$, terdapat Z3 dengan ukuran $15 / 7 \mathrm{~cm}$ dan kemiringan $40^{\circ}$. Dalam penyusunan struktur agar Z4 tidak bergeser maka terdapat X7 sebagai penahan X4. X7 memiliki ukuran $15 / 9 \mathrm{~cm}$. Diatas Z3 terdapat Z5 dengan ukuran $8 / 8 \mathrm{~cm}$ dan diatas $\mathrm{Y} 3$ terdapat X8 dengan ukuran $8 / 8 \mathrm{~cm}$. X8 berfungsi menahan Z6 yang sebagai penopang pelapis atap seng.

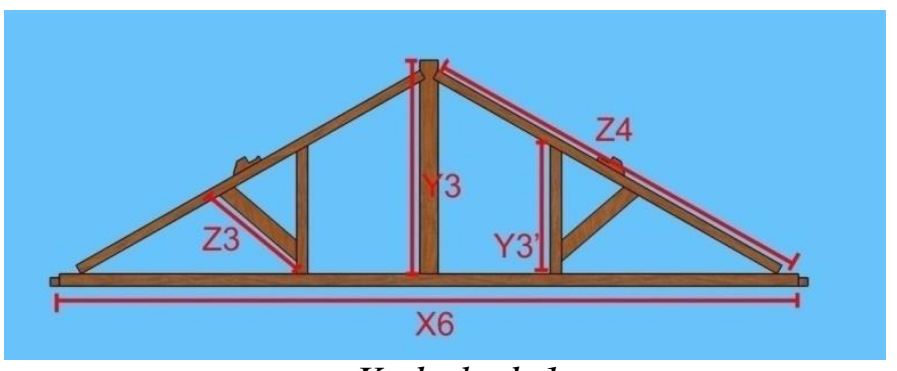

a. Kuda-kudal

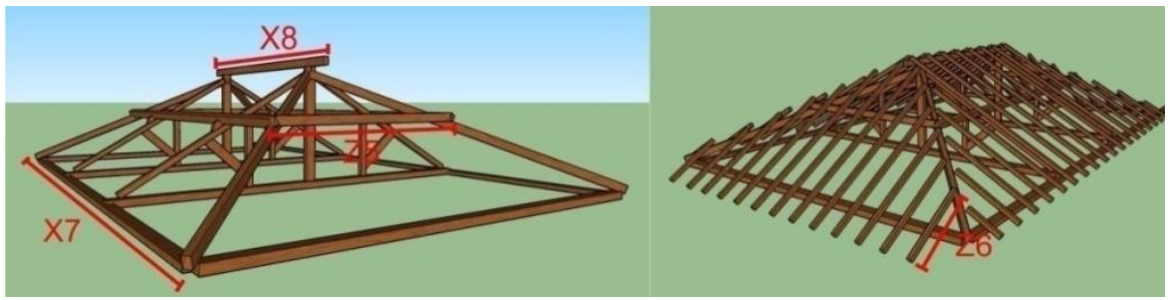

b. Struktur

Gambar 14. Segmen 2 pada Struktur Atas Rumah Tradisional Melayu di Kelurahan Bansir Laut Sumber: Penulis, 2016

Atap pada segmen 3 merupakan atap berbentuk pelana dengan fungsi sebagai penutup area dapur pada studi kasus. Ruang struktur pada atap berukuran $6 \mathrm{~m}$ x $6 \mathrm{~m}$ dengan ketinggian Y3 yaitu $0,6 \mathrm{~m}$ dengan dimensi $8 / 8 \mathrm{~cm}$. Ukuran X4 pada ruang atap segmen 3 yaitu $10 / 8 \mathrm{~cm}$ dengan material struktur X6 serta X7 berukuran $15 / 7 \mathrm{~cm}$. Pada segmen 3 ukuran Z6 yang menopang Z7 yaitu $5 / 8 \mathrm{~cm}$ dan ukuran $\mathrm{Z} 7$ sebagai penopang pelapis atap seng yaitu $3 / 5 \mathrm{~cm}$. Ukuran X8 yaitu $8 / 8 \mathrm{~cm}$ dengan panjang $6 \mathrm{~m}$. 


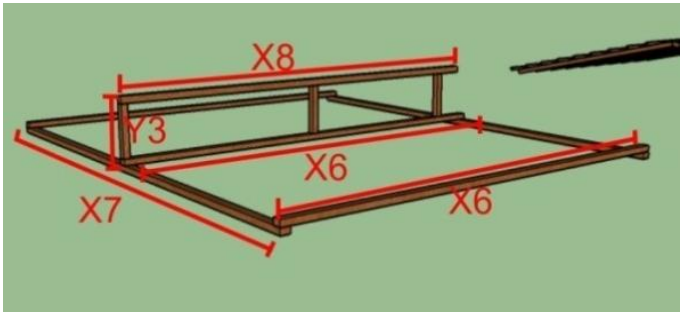

a. Struktur Kuda - Kuda Segmen 3

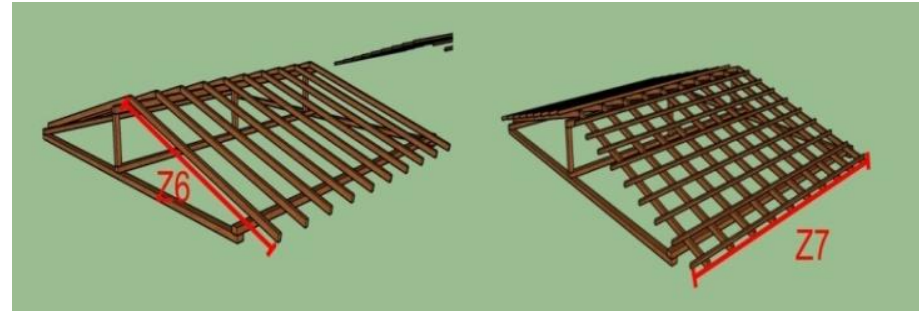

b. Struktur Atap Kuda Segmen 3

Gambar 15. Segmen 3 pada Struktur Atas Rumah Tradisional Melayu di Kelurahan Bansir Laut Sumber : Penulis, 2016

Segmen 4 merupakan segmen struktur atas yang berjenis atap pelana dengan ketinggian 1,80m dari X2. Segmen ini merupakan area dapur atau pelataran belakang yang memiliki X6 berukuran $5 / 7 \mathrm{~cm}$ dan $\mathrm{X} 7$ berukuran $5 / 7 \mathrm{~cm}$. Tinggi $\mathrm{Y} 3$ yaitu $0,5 \mathrm{~m}$ dengan ukuran $7 / 7 \mathrm{~cm}$ dan $\mathrm{Z} 6$ berukuran $5 / 6 \mathrm{~cm}$ dan kemiringan $20^{\circ}$. Z7 memiliki ukuran $3 / 5 \mathrm{~cm}$ dengan jarak antar Z7 dan jarak antar Z6 yaitu $0,5 \mathrm{~m}$ dan memiliki X8 dengan ukuran $4 / 6 \mathrm{~cm}$. Segmen 5 merupakan segmen tambahan yang berfungsi sebagai wc/kamar mandi pada studi kasus. segmen 5 memiliki grid $3 \mathrm{~m}$ x 1,5m dengan struktur atap setengah pelana yang memiliki X6 berukuran $8 / 8 \mathrm{~cm}$. Diatas X6 terdapat Z6 berukuran $5 / 6 \mathrm{~cm}$ dan memiliki kemiringan $20^{\circ}$.

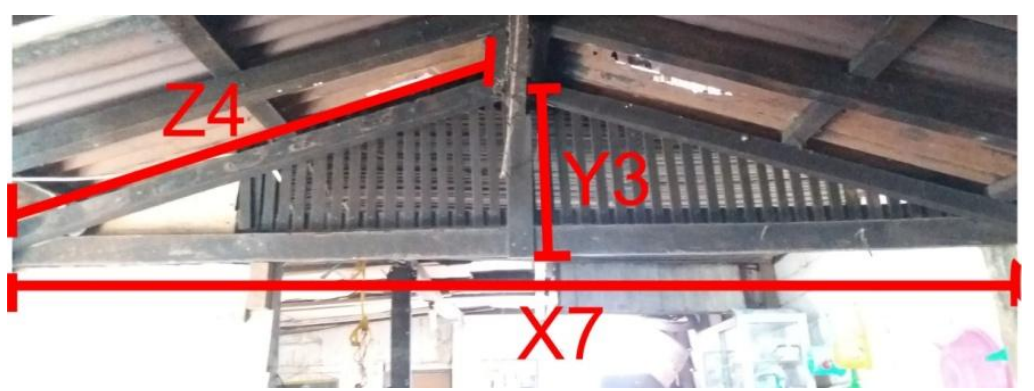

a. Struktur Kuda - Kuda Segmen 4

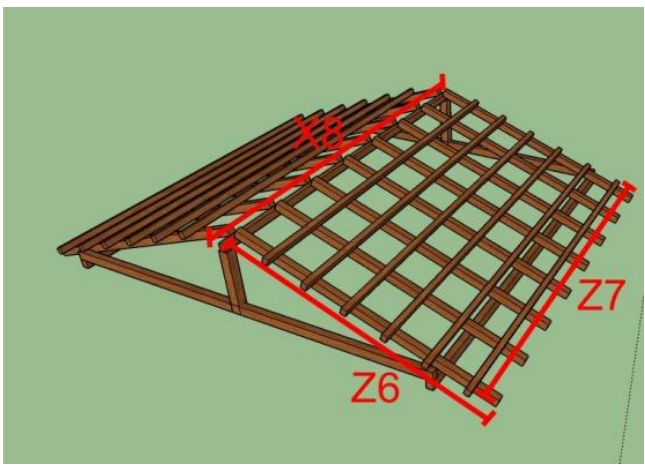

b. Perspektif Kuda - Kuda Segmen 4

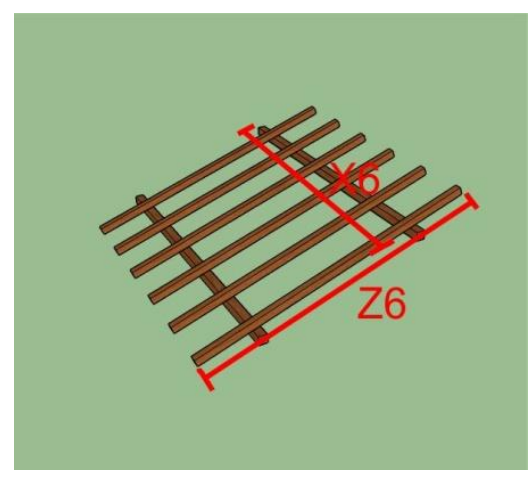

c. Perspektif Segmen 5

Gambar 15. Segmen pada Struktur Atap Rumah Tradisional Melayu di Kelurahan Bansir Laut Sumber :Penulis, 2016

\section{Pembahasan}

Berdasarkan observasi maka didapat hasil bahwa pada struktur bawah pada studi kasus terdapat tiga jenis grid yaitu grid $3 \mathrm{~m} \times 3 \mathrm{~m}$ dengan $\mathrm{Y} 1$ berukuran $15 / 15 \mathrm{~cm}$ dan $\mathrm{Y} 1$ ' berukuran 10/10cm dengan jarak antar Y1 dan Y1' yaitu 1,5m. Diatas Y1 dan Y1' terdapat X1 dengan ukuran 
$17 / 4 \mathrm{~cm}$ dan diatasnya terdapat $\mathrm{X} 2$ berukuran $5 / 5 \mathrm{~cm}$. Tinggi $\mathrm{Y} 1$ dan $\mathrm{Y} 1$ ' dari permukaan tanah yaitu $1,50 \mathrm{~m}$ dan $1,30 \mathrm{~m}$ dan dari dalam tanah ke permukaan tanah yaitu $50 \mathrm{~cm}$. Pada grid $2 \mathrm{~m} \times 1,5 \mathrm{~m}$ memiliki kesamaan pada X1 dan $Y 1$ namun berbeda pada $Y 1$ yaitu dengan ukuran $10 / 10 \mathrm{~cm}$. Pada grid 1,5m x 1,5m memiliki Y1 10/10cm dengan X1 berukuran $14 / 7 \mathrm{~cm}$ dan X2 berukuran $5 / 5 \mathrm{~cm}$.

Tabel 2. Volume ruang grid struktur bawah studi kasus

\begin{tabular}{|c|c|c|c|c|c|c|c|c|c|c|}
\hline \multicolumn{11}{|c|}{ STRUKTUR BAWAH } \\
\hline \multirow[b]{2}{*}{$\begin{array}{l}\mathrm{N} \\
\mathrm{O} .\end{array}$} & \multirow{2}{*}{$\begin{array}{c}\text { JENIS } \\
\& \\
\text { UKUR } \\
\text { AN } \\
\text { GRID } \\
(\mathrm{M})\end{array}$} & \multirow[b]{2}{*}{$\begin{array}{c}\text { JUML } \\
\text { AH } \\
\text { GRID }\end{array}$} & \multirow{2}{*}{$\begin{array}{c}\text { PANJAN } \\
\text { G } \\
\text { MATERI } \\
\text { AL } \\
\text { STRUKT } \\
\text { UR }\end{array}$} & \multicolumn{2}{|c|}{$X$} & \multicolumn{2}{|c|}{ Y } & \multirow{2}{*}{$\begin{array}{l}\mathrm{Z} \\
\mathrm{Z1}\end{array}$} & \multicolumn{2}{|c|}{$\begin{array}{c}\text { VOLUME } \\
\text { GRID }\end{array}$} \\
\hline & & & & $\mathrm{X} 1$ & $\mathrm{X} 2$ & Y1 & Y1' & & $\begin{array}{c}\text { RUA } \\
\text { NG } \\
\text { STRU } \\
\text { KTUR } \\
\left(\mathrm{M}^{3}\right)\end{array}$ & $\begin{array}{c}\text { TOT } \\
\text { AL } \\
\left(\mathrm{M}^{3}\right)\end{array}$ \\
\hline 1 & $\begin{array}{c}3 \mathrm{mx} \\
3 \mathrm{~m}\end{array}$ & 9 & 1,5 & $\begin{array}{c}17 / 4 \\
\mathrm{~cm}\end{array}$ & $\begin{array}{l}5 / 5 \\
\mathrm{~cm}\end{array}$ & $\begin{array}{c}15 / 15 \\
\mathrm{~cm}\end{array}$ & $\begin{array}{c}10 / 10 \\
\mathrm{~cm}\end{array}$ & $\begin{array}{l}4 / 4 \\
\mathrm{~cm}\end{array}$ & 13,5 & 121,5 \\
\hline 2 & $\begin{array}{l}2 \mathrm{mx} \\
1,5 \mathrm{~m}\end{array}$ & 8 & 1,5 & $\begin{array}{c}17 / 4 \\
\mathrm{~cm}\end{array}$ & $\begin{array}{l}5 / 5 \\
\mathrm{~cm}\end{array}$ & $\begin{array}{c}10 / 10 \\
\mathrm{~cm}\end{array}$ & & & 4,5 & 36 \\
\hline 3 & $\begin{array}{c}1,5 \mathrm{~m} \mathrm{x} \\
1,5 \mathrm{~m}\end{array}$ & 16 & 1 & $\begin{array}{c}17 / 4 \\
\mathrm{~cm}\end{array}$ & $\begin{array}{l}5 / 5 \\
\mathrm{~cm}\end{array}$ & $\begin{array}{c}10 / 10 \\
\mathrm{~cm}\end{array}$ & & & 2,25 & 36 \\
\hline \multicolumn{10}{|c|}{ TOTAL } & 193,5 \\
\hline
\end{tabular}

Sumber: Penulis, 2016

Perhitungan volume grid ruang untuk struktur bawah dibagi menjadi tiga segmen. Segmen pertama merupakan segmen yang memiliki grid ukuran $3 \mathrm{~m}$ x $3 \mathrm{~m}$ dan volume dalam satu buah grid sebesar $13,5 \mathrm{~m}^{3}$. Dengan grid sebanyak 9 buah serta volume total ruang struktur grid pada segmen 1 sebesar $121,5 \mathrm{~m}^{3}$. Segmen 2 merupakan grid dengan ukuran $2 \mathrm{~m}$ x 1,5m yang memiiki volume satu buah grid sebesar $4,5 \mathrm{~m}^{3}$ dan secara keseluruhan memiliki volume total ruang struktur sebesar $36 \mathrm{~m}^{3}$. Segmen 3 memiliki grid berukuran $1.5 \mathrm{~m}$ x $1.5 \mathrm{~m}$ dengan volume satu buah grid sebesar $2.25 \mathrm{~m}^{3}$ dengan grid sebanyak 16 buah dan volume total ruang struktur sebesar $36 \mathrm{~m}^{3}$. Total keseluruhan volume ruang (Vtotal) grid pada struktur bawah sebesar $193,5 \mathrm{~m}^{3}$.

Selanjutnya dilakukan perhitungan volume material struktur pada struktur bawah. Pada segmen satu dengan ukuran grid $3 \mathrm{~m}$ x $3 \mathrm{~m}$ memiliki 9 grid dengan hasil perhitungan volume material struktur seperti pada tabel 3. Ukuran volume satuan grid material struktur $\left(\mathrm{m}^{3}\right)$ dihitung dengan mengkalikan lebar x tinggi x panjang seperti pada sumbu X1 ( lebar $0,17 \mathrm{~m}$ x tinggi $0,04 \mathrm{~m}$ x panjang $3 \mathrm{~m}$ ). Secara keseluruhan pada segmen satu yang terdiri dari 9 grid dihasilkan volume total material struktur sebesar $14,12 \mathrm{~m}^{3}$. Cara yang sama dilakukan terhadap segmen 2 dan 3 sehingga dihasilkan volume material struktur pada segmen 2 sebesar $20,72 \mathrm{~m}^{3}$ dan segmen 3 sebesar $1,5 \mathrm{~m}^{3}$. Pada segmen 2 volume material struktur X2 dalam satu grid yang memiliki panjang $2 \mathrm{~m}$ memiliki volume satu grid $0,06 \mathrm{~m}^{3}$ dan pada grid yang memiliki panjang $1,5 \mathrm{~m}$ memiliki volume $0,555 \mathrm{~m}^{3}$. Pada segmen 3 jumlah ukuran satu grid yaitu $0,05 \mathrm{~m}^{3}$ dengan total volume material struktur yaitu $17,76 \mathrm{~m}^{3}$. Dari hasil perhitungan keseluruhan grid dari tiap segmen tersebut maka volume total material struktur bawah studi kasus sebesar $60,8 \mathrm{~m}^{3}$. 
Tabel 3. Volume material struktur bawah

\begin{tabular}{|c|c|c|c|c|c|c|c|c|c|c|c|c|c|c|c|c|c|c|c|c|}
\hline \multicolumn{21}{|c|}{ STRUKTUR BAWAH } \\
\hline \multirow{3}{*}{ NO. } & \multirow{3}{*}{$\begin{array}{c}\text { BANYAK } \\
\text { GRID }\end{array}$} & \multirow{3}{*}{ MATERIAL } & \multicolumn{6}{|c|}{$x$} & \multicolumn{6}{|c|}{$\mathrm{Y}$} & \multicolumn{3}{|c|}{ Z } & \multicolumn{3}{|c|}{ VOLUME GRID } \\
\hline & & & \multicolumn{3}{|c|}{ X1 } & \multicolumn{3}{|c|}{ X2 } & \multicolumn{3}{|c|}{ Y1 } & \multicolumn{3}{|c|}{ Y1' } & \multicolumn{3}{|c|}{$\mathbf{Z 1}$} & \multirow{2}{*}{$\begin{array}{c}\text { RUANG } \\
\text { STRUKTUR } \\
\text { (M3) }\end{array}$} & \multirow{2}{*}{$\begin{array}{l}\text { JUMLAH } \\
\text { (M3) }\end{array}$} & \multirow{2}{*}{$\begin{array}{l}\text { TOTAL } \\
\text { (M3) }\end{array}$} \\
\hline & & & L & T & JLH & L & T & JLH & L & T & JLH & L & T & JLH & L & T & JLH & & & \\
\hline \multirow{3}{*}{1} & \multicolumn{20}{|c|}{ SEGMEN 1 (3M X 3M) } \\
\hline & 9 & 3 & 0,17 & 0,04 & 2 & 0,05 & 0,05 & 1 & 0,15 & 0,15 & 4 & 0,1 & 0,1 & 2 & 0,04 & 0,04 & 4 & \multirow{2}{*}{0,2325} & \multirow{2}{*}{2,0925} & \multirow{2}{*}{3,90015} \\
\hline & VOLUM & SUMBU & & 0,040 & & & 0,0075 & & & 0,135 & & & 0,03 & & & 0,019 & & & & \\
\hline \multirow{5}{*}{2} & \multicolumn{20}{|c|}{ SEGMEN $2(2 \mathrm{M} \times 1,5 \mathrm{M})$} \\
\hline & 8 & 2 & 0,17 & 0,04 & 1 & 0,05 & 0,05 & 1 & 0,15 & 0,15 & 2 & & & & & & & \multirow{2}{*}{0,0861} & \multirow{2}{*}{0,6888} & \multirow{4}{*}{1,3404} \\
\hline & \multicolumn{2}{|c|}{ VOLUME SUMBU } & \multicolumn{3}{|c|}{0,0136} & & 0,005 & & \multicolumn{3}{|c|}{0,0675} & & & & & & & & & \\
\hline & 8 & 1,5 & 0,17 & 0,04 & 1 & 0,05 & 0,05 & 1 & 0,15 & 0,15 & 2 & & & & & & & \multirow{2}{*}{0,08145} & \multirow{2}{*}{0,6516} & \\
\hline & VOLUM & SUMBU & & 0,010 & & & 0,0037 & & & 0,067 & & & & & & & & & & \\
\hline & & & & & & & & & & MEN & $5 \mathrm{MX}$ & & & & & & & & & \\
\hline 3 & 16 & 1,5 & 0,17 & 0,04 & 2 & 0,05 & 0,05 & 1 & 0,15 & 0,15 & 4 & & & & & & & 0,11415 & 1,8264 & 8,88 \\
\hline & VOLUM & SUMBU & & 0,020 & & & 0,0037 & & & 0,09 & & & & & & & & 0,11410 & $1,0<04$ & 0,00 \\
\hline & & & & & & LUN & OTAL & NST & KSI S & KTUR & WA & IDI I & IS A & & & & & & & 14,12055 \\
\hline
\end{tabular}

Sumber: Penulis, 2016 
Setelah didapatkan volume ruang pada struktur bawah dan volume material struktur bawah maka dibuatlah perbandingan yaitu antara volume total material struktur dengan volume grid kemudian dibandingkan dengan volume ruang total sebagai berikut :

$$
\begin{aligned}
& \frac{\text { Vtotal Material Struktur Bawah }}{\text { VStruktur Bawah Segmen } 1}=\frac{14.12 \mathrm{~m} 3}{4 \mathrm{~m} 3}=7: 2 \\
& \frac{\text { Vtotal Material Struktur bawah }}{\text { VStruktur Bawah Segmen } 2}=\frac{14.12 \mathrm{~m} 3}{1.35 \mathrm{~m} 3}=11: 1 \\
& \frac{\text { Vtotal Material Struktur bawah }}{\text { VStruktur Bawah Segmen } 3}=\frac{14.12 \mathrm{~m} 3}{8.8 \mathrm{~m} 3}=7: 4
\end{aligned}
$$

Dari hasil perbandingan antara volume total ruang struktur terhadap volume total material pada struktur bawah $\left(193,5 \mathrm{~m}^{3} / 60,8 \mathrm{~m}^{3}\right)$ mendapatkan perandingan $3: 1$. Hasil serupa juga didapatkan komposisi perbandingan sebesar $3: 1$ dengan volume struktur bawah segmen 1. Volume total struktur bawah pada segmen 1 berbanding $3: 1$ dengan volume struktur segmen 2 dan segmen 3 . Asumsi yang didapat dari hasil perbandingan analisis antara volume total material struktur awah dengan volume struktur per segmen yaitu secara konstruksi bentuk struktur bawah pada studi kasus memiliki bentuk struktur yang sama rata.

Setelah dilihat volume segmen terhadap volume totalmaterial struktur, maka dalam satu buah grid dapat dilihat bentuk struktur yang menopang volume ruang pada struktur bawah dengan dilakukan perbandingan yaitu :

$$
\begin{aligned}
& \frac{\text { VtotalbawahSegmen } 1}{\text { VRuang Struktur Bawah Segmen 1 }}=\frac{121.5 \mathrm{~m} 3}{4 \mathrm{~m} 3}=30: 1 \\
& \frac{\text { VtotalbawahSegmen } 2}{\text { VRuang Struktur Bawah Segmen 2 }}=\frac{36 \mathrm{~m} 3}{1.35 \mathrm{~m} 3}=27: 1 \\
& \frac{\text { VtotalbawahSegmen } 3}{\text { VRuang Struktur Bawah Segmen } 3}=\frac{36 \mathrm{~m} 3}{8.8 \mathrm{~m} 3}=9: 2
\end{aligned}
$$

Dari hasil perbandingan antara volume ruang segmen terhadap grid di segmen diatas dapat diambil asumsi bahwa pada segmen satu dengan volume total struktur bawah berbanding $30: 1$ dengan volume ruang struktur. Dalam volume total material segmen kedua terhadap volume ruang segmen kedua di grid 1 memiliki perbandingan yaitu 27 : 1 . Pada segmen ke tiga volume struktur bawah berbanding $9: 2$ dengan volume ruang struktur segmen 3 grid 1. Dari hasil perbandingan dapat disimpulkan bahwa dalam volume material struktur bawah tiap segmen berbanding lebih kecildari totalan volume ruang struktur secara keseluruhan. Kesimpulan lain dapat dibuat dengan perhitungan total antara volume konstruksi total struktur bawah dan volume total ruang struktur bawah :

$$
\frac{\text { Vtotal Ruang Struktur bawah }}{\text { Vtotal Material Struktur bawah }}=\frac{193.5 \mathrm{~m} 3}{14.12 \mathrm{~m} 3}=13: 1
$$

Struktur tengah studi kasus memiliki tiga jenis grid yaitu grid berukuran $3 \mathrm{~m} \times 3 \mathrm{~m}$ dengan ukuran Y2 sebesar $8 / 8 \mathrm{~cm}$ dan Y2' berukuran $8 / 8 \mathrm{~cm}$. Pada material struktur X3 memiliki ukuran sebesar $8 / 8 \mathrm{~cm}$. Grid pada struktur tengah dibedakan dari jarak antar Y2. Pada Grid berukuran $2 \mathrm{~m}$ x $3 \mathrm{~m}$ ukuran Y2 dan Y2' yaitu $8 / 8 \mathrm{~cm}$ dengan X3 berukuran $8 / 8 \mathrm{~cm}$. Grid $1,5 \mathrm{~m}$ x $1,5 \mathrm{~m}$ juga memiliki persamaan ukuran material $\mathrm{Y} 2$ dan $Y 2$ ' yaitu $8 / 8 \mathrm{~cm}$ dan ukuran X3 yaitu $8 / 8 \mathrm{~cm}$. Struktur tengah pada studi kasus memiliki tiga jenis ukuran grid yaitu $3 \mathrm{~m} \times 3 \mathrm{~m}$ dengan grid sebanyak 11 buah, $2 \mathrm{~m} \times 3 \mathrm{~m}$ dengan grid sebanyak satu buah dan $1.5 \mathrm{~m} \times 1.5 \mathrm{~m}$ dengan grid sebanyak 3 buah. 
Tabel 4. Volume ruang grid pola struktur tengah

\begin{tabular}{|c|c|c|c|c|c|c|c|c|c|c|c|}
\hline \multirow[b]{3}{*}{$\begin{array}{l}\mathrm{N} \\
\mathrm{O} .\end{array}$} & \multicolumn{11}{|c|}{ STRUKTUR TENGAH } \\
\hline & \multirow{2}{*}{$\begin{array}{c}\text { JENIS } \\
\& \\
\text { UKUR } \\
\text { AN } \\
\text { GRID }\end{array}$} & \multirow{2}{*}{$\begin{array}{c}\text { PANJAN } \\
\text { G } \\
\text { BENTU } \\
\text { K } \\
\text { STRUKT } \\
\text { UR }\end{array}$} & \multirow[b]{2}{*}{$\begin{array}{c}\text { JUMLA } \\
\mathrm{H}\end{array}$} & \multicolumn{3}{|c|}{$\mathrm{X}$} & \multicolumn{2}{|c|}{ Y } & \multirow{2}{*}{$\begin{array}{c}\mathrm{Z} \\
\mathrm{Z8}\end{array}$} & \multicolumn{2}{|c|}{$\begin{array}{l}\text { VOLUME } \\
\text { GRID }\end{array}$} \\
\hline & & & & X3 & $\begin{array}{l}X \\
4\end{array}$ & $\begin{array}{l}X \\
5\end{array}$ & Y2 & Y' & & $\begin{array}{l}\text { RUAN } \\
\text { G } \\
\text { STRU } \\
\text { KTUR } \\
\text { (M3) }\end{array}$ & $\begin{array}{l}\text { TOTA } \\
\text { L (M3) }\end{array}$ \\
\hline 1 & $\begin{array}{c}3 \mathrm{mx} \\
3 \mathrm{~m}\end{array}$ & 3,5 & 11 & $\begin{array}{l}8 / 8 \\
\mathrm{~cm}\end{array}$ & & & $\begin{array}{l}8 / 8 \\
\mathrm{~cm}\end{array}$ & $\begin{array}{l}8 / 8 \\
\mathrm{~cm}\end{array}$ & & 31,5 & 346,5 \\
\hline 2 & $\begin{array}{c}2 \mathrm{mx} \\
3 \mathrm{~m}\end{array}$ & 3 & 1 & $\begin{array}{l}8 / 8 \\
\mathrm{~cm}\end{array}$ & & & $\begin{array}{l}8 / 8 \\
\mathrm{~cm}\end{array}$ & $\begin{array}{l}8 / 8 \\
\mathrm{~cm} \\
\end{array}$ & & 18 & 18 \\
\hline 3 & $\begin{array}{c}1,5 \mathrm{~m} \mathrm{x} \\
1,5 \mathrm{~m}\end{array}$ & 2 & 3 & $\begin{array}{l}8 / 8 \\
\mathrm{~cm} \\
\end{array}$ & & & $\begin{array}{l}8 / 8 \\
\mathrm{~cm}\end{array}$ & $\begin{array}{l}8 / 8 \\
\mathrm{~cm}\end{array}$ & & 4,5 & 13,5 \\
\hline \multicolumn{11}{|c|}{ TOTAL } & 378 \\
\hline
\end{tabular}

Sumber: Penulis, 2016

Dari hasil volume grid struktur tengah pada tabel 5 dapat dilihat bahwa struktur tengah studi kasus terbagi menjadi tiga segmen. Segmen pertama merupakan segmen dengan ukuran grid $3 \mathrm{~m} \times 3 \mathrm{~m}$ yang memiliki panjang (ketinggian ruang) yaitu $3,5 \mathrm{~m}$ sehingga dalam satu grid yang berukuran $3 \mathrm{~m} \times 3 \mathrm{~m}$ didapatkan hasil volume sebesar $31,5 \mathrm{~m}^{3}$ dengan volume total ruang segmen 1 yang berjumlah 12 grid yaitu $378 \mathrm{~m}^{3}$. Segmen 2 terdiri dari grid yang berukuran $2 \mathrm{~m}$ $\mathrm{x} 3 \mathrm{~m}$ dengan panjang $3 \mathrm{~m}$ dan memiliki volume ruang dalam satu grid yaitu $18 \mathrm{~m} 3$ dan total ruang segmen yang terdiri dari dua buah grid yaitu $36 \mathrm{~m}^{3}$. Segmen ketiga terdiri dari grid berukuran $1.5 \mathrm{~m} \times 1.5 \mathrm{~m}$ dengan panjang $2 \mathrm{~m}$ yang memiliki ukuran volume satu buah grid yaitu $4,5 \mathrm{~m}^{3}$ dan volume total keseluruhan segmen tiga yaitu $13,5 \mathrm{~m}^{3}$. Dari ketiga segmen ini didapatkanlah Vtotal Ruang Tengah $=378 \mathrm{~m}^{3}$.

Struktur tengah yang terdiri dari tiga segmen dibagi menjadi beberapa grid. Segmen pertama yang mempunyai grid berukuran $3 \mathrm{~m}$ x $3 \mathrm{~m}$ memiliki 11 grid dengan 7 buah grid yang berbeda volume. Grid pertama memiliki volume $0,192 \mathrm{~m}^{3}$ dengan jumlah grid satu buah. Grid kedua bervolume $0,178 \mathrm{~m}^{3}$, grid ketiga memiliki volume $0,2304 \mathrm{~m}^{3}$ dengan jumlah grid dua buah. Grid keempat bervolume $0,11 \mathrm{~m}^{3}$ grid kelima berukuran $0,6 \mathrm{~m}^{3}$ grid keenam memiliki ukuran $0,844 \mathrm{~m}^{3}$ dan grid ke tujuh memiliki ukuran $0,53 \mathrm{~m}^{3}$ dan total volume konstruksi segmen 1 struktur tengah yaitu $3 \mathrm{~m}^{3}$.

Segmen kedua terdiri dari grid berukuran $2 \mathrm{~m}$ x $3 \mathrm{~m}$ dengan jumlah grid sebanyak dua buah. Volume satu buah grid pada segmen dua yaitu $0,08 \mathrm{~m} 3$ dengan total volume material segmen dua yaitu $0,08 \mathrm{~m}^{3}$. Segmen ketiga berukuran $1,5 \mathrm{~m}$ x $1,5 \mathrm{~m}$ dengan ukuran volume segmen tiga yaitu $0,8 \mathrm{~m}^{3}$. Dari perhitungan ketiga segmen struktur tengah pada studi kasus maka dibuat perhitungan yaitu :

$$
\begin{aligned}
& \frac{\text { Vtotal Material Struktur Tengah }}{\text { VStruktur Tengah Segmen } 1}=\frac{3.8 \mathrm{~m} 3}{3 \mathrm{~m} 3}=4: 3 \\
& \frac{\text { Vtotal Material Struktur Tengah }}{\text { VStruktur Tengah Segmen } 2}=\frac{3.8 \mathrm{~m} 3}{0.08 \mathrm{~m} 3}=47: 1 \\
& \frac{\text { Vtotal Material Struktur Tengah }}{\text { VStruktur Tengah Segmen } 3}=\frac{3.8 \mathrm{~m} 3}{0.8 \mathrm{~m} 3}=5: 1
\end{aligned}
$$

Dari hasil perbandingan antara volume total material struktur tengah dengan volume struktur per segmen terlihat bahwa pada segmen satu volume material berbanding $4: 3$ dengan volume material segmen satu. Pada segmen kedua volume total material berbanding 47 : 1 dengan volume material segmen dua dan pada segmen ketiga volume material struktur 
berbanding $5: 1$ dengan volume material struktur per segmen. Dari hasil perbandingan dapat diasumsikan bahwa ukuran volume material struktur yang dihasilkan tiap segmen berbeda beda menyesuaikan kebutuhan ruang terhadap grid yang membentuk tiap segmen dan tiap ruang - ruang di grid tersebut. Setelah perbandingan volume materialstruktur, maka dalam satu buah grid dilihat bentuk struktur yang menopang volume ruang pada struktur bawah dengan dilakukan perbandingan yaitu :

$$
\begin{aligned}
& \frac{\text { Vtotal struktur tengahS } 1}{\text { Vstruktur tengah } \mathrm{S} 1}=\frac{346 \mathrm{~m} 3}{3 \mathrm{~m} 3}=115: 1 \\
& \frac{\text { Vtotal struktur tengahS } 2}{\text { Vstruktur tengah } \mathrm{S} 2}=\frac{36 \mathrm{~m} 3}{0.08 \mathrm{~m} 3}=450: 1 \\
& \frac{\text { Vtotal struktur tengahS } 3}{\text { Vstruktur tengah S3 }}=\frac{18 \mathrm{~m} 3}{0.8 \mathrm{~m} 3}=225: 1
\end{aligned}
$$

Dari hasil perbandingan antara volume ruang segmen terhadap grid di segmen diatas dapat diambil asumsi bahwa pada segmen satu dengan volume total struktur bawah berbanding 155 : 1 dengan volume ruang struktur. Dalam volume total ruangstruktur segmen kedua terhadap volume material segmen kedua di grid 1 memiliki perbandingan yaitu $450: 1$. Pada segmen ke tiga volume ruang struktur bawah berbanding 225: 1 dengan volume material struktur segmen tiga grid satu. Dari hasil perbandingan dapat disimpulkan bahwa dalam volume ruang struktur tengah tiap segmen berbanding lebih kecil dari totalan volume material secara keseluruhan. Kesimpulan lain dapat dibuat dengan perhitungan total antara volume total struktur tengah dan volume total ruang struktur tengah sebesar:

$$
\frac{\text { Vtotal Ruang Struktur tengah }}{\text { VMaterial Struktur tengah }}=\frac{378 \mathrm{~m} 3}{3.8 \mathrm{~m} 3}=100: 1
$$


Tabel 5. Volume konstruksi grid pola struktur tengah

\begin{tabular}{|c|c|c|c|c|c|c|c|c|c|c|c|c|c|c|c|c|c|c|c|c|c|c|c|}
\hline \multicolumn{24}{|c|}{ STRUKTUR TENGAH } \\
\hline \multirow{3}{*}{ No. } & \multirow{3}{*}{$\begin{array}{c}\text { BANYAK } \\
\text { GRID }\end{array}$} & \multirow{3}{*}{ MATERIAL } & \multicolumn{9}{|c|}{$\mathrm{x}$} & \multicolumn{6}{|c|}{$Y$} & \multirow{2}{*}{\multicolumn{3}{|c|}{$\begin{array}{c}\mathrm{Z} \\
\mathrm{Z} 8\end{array}$}} & \multicolumn{3}{|c|}{ VOLUME GRID } \\
\hline & & & \multicolumn{3}{|c|}{ X3 } & \multicolumn{3}{|c|}{$\mathrm{X} 4$} & \multicolumn{3}{|c|}{ X5 } & \multicolumn{3}{|c|}{ Y2 } & \multicolumn{3}{|c|}{ Y2' } & & & & \multirow{2}{*}{$\begin{array}{l}\text { RUANG } \\
\text { STRUKTUR } \\
\text { (M3) }\end{array}$} & \multirow{2}{*}{$\begin{array}{l}\text { JUMLAH } \\
\text { (M3) }\end{array}$} & \multirow{2}{*}{ TOTAL (M3) } \\
\hline & & & $\mathrm{L}$ & $T$ & JLH & $\mathrm{L}$ & $T$ & JLH & $\mathrm{L}$ & $T$ & JLH & $\mathrm{L}$ & $T$ & $\mathrm{JLH}$ & $\mathrm{L}$ & $T$ & JLH & $\mathrm{L}$ & $\begin{array}{lll}T \\
\end{array}$ & JLH & & & \\
\hline \multirow{15}{*}{1} & \multicolumn{23}{|c|}{ SEGMEN 1 (3MX 3M) } \\
\hline & 1 & 3 & 0,08 & 0,08 & 3 & & & & & & & 0,08 & 0,08 & 4 & 0,08 & 0,08 & 3 & & & & \multirow{2}{*}{0,192} & \multirow{2}{*}{0,192} & \\
\hline & \multicolumn{2}{|c|}{ VOLUME SUMBU } & \multicolumn{3}{|c|}{0,0576} & & & & & & & \multicolumn{3}{|c|}{0,0768} & \multicolumn{3}{|c|}{0,0576} & & & & & & \\
\hline & 1 & 3 & 0,08 & 0,08 & 2 & & & & & & & 0,08 & 0,08 & 4 & 0,08 & 0,08 & 3 & & & & 0.1728 & 0.1728 & \\
\hline & VOLUME & E SUMBU & & 0,038 & & & & & & & & & 0,0768 & & & 0,057 & & & & & $0,1>0$ & $x+1<0$ & \\
\hline & 2 & 3 & 0,08 & 0,08 & 1 & & & & & & & 0,08 & 0,08 & 4 & 0,08 & 0,08 & 1 & & & & 0,2304 & 0,4608 & \\
\hline & VOLUME & E SUMBU & & 0,019 & & & & & & & & & 0,0768 & & & 0,019 & & & & & 0,2304 & 0,4000 & \\
\hline & 1 & 3 & 0,08 & 0,08 & 1 & & & & & & & 0,08 & 0,08 & 2 & 0,08 & 0,08 & 3 & & & & 0.1152 & 0.1152 & 29376 \\
\hline & VOLUME & E SUMBU & & 0,0192 & & & & & & & & & 0,0384 & & & 0,057 & & & & & לתהע, & 20, & טובכוג \\
\hline & 2 & 3 & 0,08 & 0,08 & 2 & & & & & & & 0,08 & 0,08 & 4 & 0,08 & 0,08 & 2 & & & & 03072 & 0,6144 & \\
\hline & VOLUME & E SUMBU & & 0,038 & & & & & & & & & 0,0768 & & & 0,038 & & & & & 8,008 & $0,014+4$ & \\
\hline & 2 & 3 & 0,08 & 0,08 & 3 & & & & & & & 0,08 & 0,08 & 4 & 0,08 & 0,08 & 4 & & & & 0,4224 & 0,8448 & \\
\hline & VOLUME & E SUMBU & & $0,057 €$ & & & & & & & & & 0,0768 & & & 0,076 & & & & & $0,4<24$ & & \\
\hline & 2 & 3 & 0,08 & 0,08 & 1 & & & & & & & 0,08 & 0,08 & 4 & 0,08 & 0,08 & 2 & & & & 02688 & 05376 & \\
\hline & VOLUME & E SUMBU & & 0,0192 & & & & & & & & & 0,0768 & & & 0,038 & & & & & 0,2000 & שונכנוס & \\
\hline & & & & & & & & & & & SEGN & $\mathrm{N} 2(2 \mathrm{~N}$ & $\times 3 \mathrm{M})$ & & & & & & & & & & \\
\hline 2 & 1 & 2 & 0,08 & 0,08 & 3 & & & & & & & 0,08 & 0,08 & 2 & 0,08 & 0,08 & 2 & & & & 0,0896 & 0,0896 & 0,0896 \\
\hline & VOLUME & E SUMBU & & 0,038 & & & & & & & & & 0,0256 & & & 0,025 & & & & & & & \\
\hline & & & & & & & & & & & SEGME & $3(1,5)$ & $\mathrm{X} 1,5 \mathrm{M})$ & & & & & & & & & & \\
\hline 3 & 3 & 1,5 & 0,08 & 0,08 & 2 & & & & & & & 0,08 & 0,08 & 6 & 0,08 & 0,08 & 2 & & & & 0.288 & 0.864 & 0864 \\
\hline & VOLUME & E SUMBU & & 0,0192 & & & & & & & & & 0,0576 & & & 0,019 & & & & & 0,200 & 0,004 & 0,004 \\
\hline & & & & & & & & JME & & TH & STRUK & R TEN & AH STU & KASU & & & & & & & & & 3,8912 \\
\hline
\end{tabular}

Sumber: Penulis, 2016 
Tabel 6. Volume ruang grid pola struktur atas studi kasus

\begin{tabular}{|c|c|c|c|c|c|c|c|c|c|c|c|c|c|c|}
\hline \multirow{3}{*}{$\begin{array}{l}\mathrm{N} \\
\mathrm{O}\end{array}$} & \multicolumn{14}{|c|}{ STRUKTUR ATAS } \\
\hline & \multirow{2}{*}{$\begin{array}{c}\text { JENI } \\
\text { S \& } \\
\text { UKU } \\
\text { RAN } \\
\text { GRI } \\
\text { D }\end{array}$} & \multirow{2}{*}{$\begin{array}{c}\text { PANJA } \\
\text { NG } \\
\text { BENTU } \\
\text { K } \\
\text { STRUK } \\
\text { TUR }\end{array}$} & \multirow[b]{2}{*}{$\begin{array}{c}\text { BANY } \\
\text { AK } \\
\text { GRID }\end{array}$} & \multicolumn{3}{|c|}{$\mathrm{X}$} & \multirow{2}{*}{$\begin{array}{c}\mathrm{Y} \\
\mathrm{Y} 3\end{array}$} & \multicolumn{6}{|c|}{$\mathrm{Z}$} & \multirow{2}{*}{$\begin{array}{c}\text { LUAS } \\
\text { TOT } \\
\text { AL } \\
\text { GRID } \\
\left(\mathrm{M}^{3}\right)\end{array}$} \\
\hline & & & & X6 & $\mathrm{X} 7$ & X8 & & $\begin{array}{l}Z \\
2\end{array}$ & $\mathrm{Z3}$ & $\mathrm{Z4}$ & $\mathrm{Z} 5$ & Z6 & $\mathrm{Z7}$ & \\
\hline 1 & $\begin{array}{l}10,5 \\
\mathrm{mx} \\
3 \mathrm{~m} \\
\end{array}$ & 0,8 & 1 & & $\begin{array}{c}15 / 7 \mathrm{c} \\
\mathrm{m}\end{array}$ & & & & & & & $\begin{array}{l}6 / 7 \\
\mathrm{~cm}\end{array}$ & $\begin{array}{l}3 / 5 \\
\mathrm{~cm}\end{array}$ & 25,2 \\
\hline 2 & $\begin{array}{c}6 \mathrm{~m} \mathrm{x} \\
9 \mathrm{~m}\end{array}$ & 1,5 & 1 & $\begin{array}{l}10 / 1 \\
5 \mathrm{~cm}\end{array}$ & $\begin{array}{c}15 / 9 c \\
m\end{array}$ & $\begin{array}{l}8 / 8 \\
\mathrm{~cm}\end{array}$ & $\begin{array}{l}15 / \\
7 \mathrm{c} \\
\mathrm{m}\end{array}$ & & $\begin{array}{l}15 / \\
7 \mathrm{c} \\
\mathrm{m}\end{array}$ & $\begin{array}{l}8 / 8 \\
\mathrm{~cm}\end{array}$ & $\begin{array}{c}8 / 8 \mathrm{c} \\
\mathrm{m}\end{array}$ & & & 81 \\
\hline 3 & $\begin{array}{c}5 \mathrm{mx} \\
6 \mathrm{~m}\end{array}$ & 1 & 1 & $\begin{array}{c}15 / 7 \\
\mathrm{~cm}\end{array}$ & $\begin{array}{c}15 / 7 \mathrm{c} \\
\mathrm{m}\end{array}$ & $\begin{array}{l}8 / 8 \\
\mathrm{~cm}\end{array}$ & $\begin{array}{l}8 / 8 \\
\mathrm{~cm}\end{array}$ & & & & & $\begin{array}{l}5 / 8 \\
\mathrm{~cm}\end{array}$ & $\begin{array}{l}3 / 5 \\
\mathrm{~cm}\end{array}$ & 30 \\
\hline 4 & $\begin{array}{c}3 \mathrm{mx} \\
3 \mathrm{~m}\end{array}$ & 0,6 & 1 & $\begin{array}{c}5 / 7 \mathrm{c} \\
\mathrm{m}\end{array}$ & $5 / 7 \mathrm{~cm}$ & $\begin{array}{l}4 / 6 \\
\mathrm{~cm}\end{array}$ & & & $\begin{array}{l}7 / 7 \\
\mathrm{~cm}\end{array}$ & & & $\begin{array}{l}5 / 6 \\
\mathrm{~cm}\end{array}$ & $\begin{array}{l}5 / 7 \\
\mathrm{~cm}\end{array}$ & 5,4 \\
\hline 5 & $\begin{array}{l}3 \mathrm{~m} \mathrm{x} \\
1,5 \mathrm{~m}\end{array}$ & 0,5 & 1 & $\begin{array}{c}8 / 8 \mathrm{c} \\
\mathrm{m}\end{array}$ & & & & & & & & $\begin{array}{l}5 / 6 \\
\mathrm{~cm}\end{array}$ & & 2,25 \\
\hline & & & & & TOT & & & & & & & & & $\begin{array}{r}143,8 \\
5\end{array}$ \\
\hline
\end{tabular}

Sumber: Penulis, 2016

Struktur atas pada studi kasus terbagi menjadi lima segmen. Segmen 1 merupakan grid dengan ukuran $10 \mathrm{~m}$ x $3 \mathrm{~m}$ dengan atap merupakan atap setengah pelana. Segmen 2 merupakan atap utama pada studi kasus dengan ukuran $6 \mathrm{~m}$ x 9m. Atap ketiga adalah atap area dapur dengan ukuran $5 \mathrm{~m} \times 6 \mathrm{~m}$ dengan atap berbentuk pelana dan pelapis atap berupa atap seng. segmen 4 merupakan area pelataran belakang dengan grid $3 \mathrm{~m} \times 3 \mathrm{~m}$ dan merupakan atap pelana dengan penutup atap seng. Segmen 5 adalah atap untuk wc/kamar mandi dengan ukuran $3 \mathrm{~m} \times 1,5 \mathrm{~m}$ dan mempunyai penutup atap berupa seng.

Dari hasil perhitungan grid struktur atas studi kasus terdapat 5 segmen yang terhitung sebagai grid dengan satu kesatuan. Pada segmen satu dengan ukuran grid $10,5 \mathrm{~m} \times 3 \mathrm{~m}$ memiliki ruang dengan volume $25,2 \mathrm{~m}^{3}$. Pada segmen dua yang terdiri dari grid berukuran $6 \mathrm{~m}$ x $9 \mathrm{~m}$ memiliki volume ruang grid yaitu $81 \mathrm{~m}^{3}$. Pada segmen ketiga dengan grid berukuran $5 \mathrm{~m}$ x $6 \mathrm{~m}$ memiliki grid bervolume $30 \mathrm{~m}^{3}$.Pada segmen empat dengan ukuran grid $3 \mathrm{~m} \times 3 \mathrm{~m}$ memiliki volume grid yaitu $5,4 \mathrm{~m}^{3}$ dan pada segmen kelima yang berukuran $3 \mathrm{~m} \times 1.5 \mathrm{~m}$ memiliki ukuran volume grid yaitu $4,5 \mathrm{~m}^{3}$. Dari hasil perhitungan dapat dilihat pada tabel 6 yaitu volume total struktur ruang atas sebesar $143,85 \mathrm{~m}^{3}$.

Struktur atas pada studi kasus terdiri dari 5 segmen dengan segmen satu berukuran $10,5 \mathrm{~m} \times 2 \mathrm{~m}$ dengan volume material pada segmen satu yaitu $0,21 \mathrm{~m}^{3}$ dengan bentuk atap yaitu setengah pelana. Pada segmen dua yang berukuran grid $6 \mathrm{~m} \times 9 \mathrm{~m}$ memiliki volume material yaitu $3.8 \mathrm{~m}^{3}$ dengan bentuk atap berupa perisai. Segmen tiga dengan grid berukuran $5 \mathrm{~m} \times 6 \mathrm{~m}$ memiliki volume material $2,05 \mathrm{~m}^{3}$ dengan atap berupa atap pelana. Pada segmen empat dengan grid berukuran $3 \mathrm{~m}$ x $3 \mathrm{~m}$ memiliki volume material segmen yaitu $0,75 \mathrm{~m}^{3}$ dengan atap jenis pelana. Dan pada segmen lima dengan grid $3 \mathrm{~m} \times 1.5 \mathrm{~m}$ memiliki volume $0,04 \mathrm{~m}^{3}$ dengan atap setengah pelana. Total keseluruhan volume Vstruktur atas $=6,8 \mathrm{~m} 3$. 


$$
\begin{array}{cc}
\frac{\text { Vtotalstrukturatas }}{\text { Vstruktur atas } \mathrm{S} 1}=\frac{6.8 \mathrm{~m} 3}{0.21 \mathrm{~m} 3}=32: 1 & \frac{\text { Vtotalstrukturatas }}{\text { Vstruktur atas } \mathrm{S} 2}=\frac{6.8 \mathrm{~m} 3}{3.8 \mathrm{~m} 3}=3: 1 \\
\frac{\text { Vtotalstrukturatas }}{\text { Vstruktur atas S3 }}=\frac{6.8 \mathrm{~m} 3}{2.05 \mathrm{~m} 3}=4: 1 & \frac{\text { Vtotalstrukturatas }}{\text { Vstruktur atas } \mathrm{S} 4}=\frac{6.8 \mathrm{~m} 3}{0.75 \mathrm{~m} 3}=9: 1 \\
\frac{\text { Vtotalstrukturatas }}{\text { Vstruktur atas } \mathrm{S} 5}=\frac{6.8 \mathrm{~m} 3}{0.04 \mathrm{~m} 3}=170: 1
\end{array}
$$

Dari hasil perbandingan antara volume total konstruksi atas dan volume konstruksi per segmen maka didapatkan hasil yaitu pada segmen satu memiliki perbandingan $32: 1$ dengan volume total, pada segmen dua berbanding $3: 1$ dengan volume total, segmen ketiga berbanding $4: 1$, segmen 4 berbanding $9: 1$ dan segmen kelima berbanding $170: 1$. Dengan perbandingan antara volume total dan volume grid tiap segmen maka beban yang disalurkan struktur atas dapat terlihat jelas. Setelah perbandingan antara segmen dan volume konstruksi total maka dilakukan perbandingan volume total ruang dengan volume konstruksi yaitu :

$$
\begin{array}{cc}
\begin{array}{cc}
\text { VtotalatasS } 1 \\
\text { Vstruktur S1 }
\end{array}=\frac{25.2 \mathrm{~m} 3}{0.21 \mathrm{~m} 3}=120: 1 & \frac{\text { VtotalatasS } 2}{\text { Vstruktur S2 }}=\frac{81 \mathrm{~m} 3}{3.8 \mathrm{~m} 3}=21: 1 \\
\begin{array}{c}
\text { VtotalatasS } 3 \\
\text { Vstruktur S3 }
\end{array}=\frac{30 \mathrm{~m} 3}{2.05 \mathrm{~m} 3}=15: 1 & \frac{\text { VtotalatasS } 4}{\text { Vstruktur S4 }}=\frac{5.4 \mathrm{~m} 3}{0.75 \mathrm{~m}}=7: 1 \\
\frac{\text { VtotalatasS } 5}{\text { Vstruktur S5 }}=\frac{4.5 \mathrm{~m} 3}{0.04 \mathrm{~m} 3}=112: 1
\end{array}
$$

Dari hasil perbandingan antara volume ruang struktur segmen terhadap grid di segmen diatas dapat diambil asumsi bahwa pada segmen satu dengan volume total struktur bawah berbanding 120:1 terhadap volume material struktur grid. Dalam volume ruang struktur segmen 2 terhadap volume material struktur segmen 2 memiliki perbandingan yaitu $21: 1$. Pada segmen 3 volume struktur atas berbanding $15: 1$ dengan perbandingan di segmen 3 yaitu $7: 1$. Segmen 4 memiliki perbandingan $2: 1$ dan segmen 5 memiliki perbandingan 112 : 1. Dari hasil perbandingan dapat disimpulkan bahwa dalam volume ruang struktur atas tiap segmen memiliki perbandingan yang berbeda - beda tergantung pada ukuran, jenis atap serta beban yang disalurkan struktur atap terhadap bentuk - bentuk struktur lainnya. Kesimpulan ini dapat dilihat pada perbandingan volume total ruang terhadap volume total struktur yaitu :

$$
\frac{\text { Vtotal Ruang atap }}{\text { Vtotal material Struktur atap }}=\frac{143.85 \mathrm{~m} 3}{6.8 \mathrm{~m} 3}=28: 1
$$

Perhitungan volume grid struktur yang terbagi atas struktur bawah, tengah dan atas yang dihitung berdasarkan perbandingan volume total dan volume struktur antar segmen kemudian dihitung kembali secara keseluruhan bangunan dengan membandingkan struktur bawah terhadap struktur tengah dan struktur atas.

$$
\begin{array}{ll}
\mathrm{V}_{\text {total bawah }} & =193.5 \mathrm{~m}^{3} \\
\mathrm{~V}_{\text {total Tengah }} & =378 \mathrm{~m}^{3} \\
\mathrm{~V}_{\text {totalAtas }} & =143.85 \mathrm{~m}^{3} \\
& \\
\mathrm{~V}_{\text {totalbawah }}: \mathrm{V}_{\text {totalTengah }}+\mathrm{V}_{\text {totalAtas }} \\
193.5 \mathrm{~m}^{3}: 378 \mathrm{~m}^{3}+143.85 \mathrm{~m}^{3} \\
193.5 \mathrm{~m}^{3}: 521.85 \mathrm{~m}^{3} \\
1: 2.5
\end{array}
$$

Komparasi total ruang grid struktur secara keseluruhan yaitu $1: 2.5$ yang berarti struktur bawah berbanding $1: 2.5$ dengan struktur atas dan tengah. Ruang pada struktur bawah menopang 1/ 2,5 dari total keseluruhan ruang grid pada studi kasus. 


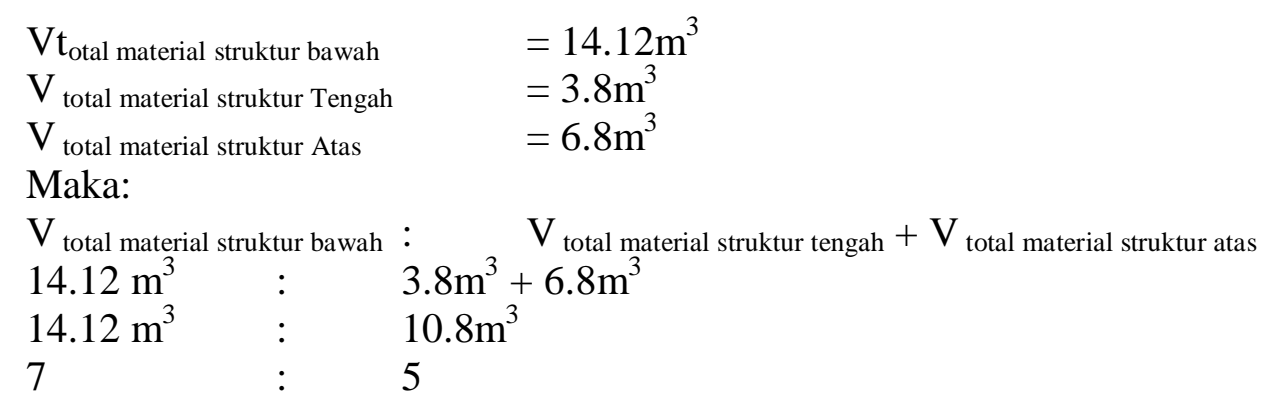

Jika secara volume ruang grid Vtotal tengah + Vtotal atas lebih besar dari Vtotal bawah, maka dalam Vtotal struktur bawah lebih besar. Hal ini dapat disimpulkan bahwa struktur bawah menopang 7/5 dari total konstruksi struktur bawah dan struktur atas. Dengan komparasi antarastruktur tengah, bawah dan atas maka disimpulkan bahwa volume material pada grid struktur bawah di studi kasus harus lebih besar dari volume material struktur tengah. Hal ini sebagai konsekuensi grid struktur bawah menjadi elemen yang menopang struktur tengah dan atas bangunan rumah tradisional.

\section{Kesimpulan}

Dari hasil analisis terhadap rumah tradisional Melayu di Kelurahan Bansir Laut Kecamatan Pontianak Tenggara Kota Pontianak maka diperoleh kesimpulan sebagai berikut:

- Dalam rumah Tradisional Melayu, struktur bawah menopang 7/5 dari total konstruksi struktur tengah dan atas. Maka, volume material pada grid struktur bawah lebih besar dari volume material struktur tengah dan atas. Dari perbandingan ini dapat disimpulkan bahwa penggunaan material struktur bawah yang terlalu besar menyebabkan keborosan struktur jika dibandingan dengan volume ruang yang dinaungi.

- Pola pada grid struktur bawah rumah Tradisional Melayu membentuk ruang - ruang dalam menciptakan suatu bangunan dengan volume struktur yang dihasilkan dapat menyesuaikan keperluan akan kebutuhan ruang.

- Besarnya volume material struktur bawah dibanding dengan struktur tengah dan atas dimaksudkan untuk menciptakan sebuah bangunan yang tersusun sesuai dengan pola yang dibentuk dari bawah ke atas.

\section{Daftar Pustaka}

Khaliesh, Hamdil. (2014). Arsitektur Tradisional Tionghoa: Tinjauan Terhadap Identitas, Karakter Budaya Dan Eksistensinya. Langkau Betang; Jurnal Arsitektur Universitas Tanjungpura (LANTANG UNTAN), Vol 1 No 1 (2014). Program Studi Arsitektur Universitas Tanjungpura. Pontianak

Lestari; Zairin Zain; Rudiyono; Irwin. (2016). Mengenal Arsitektur Lokal : Konstruksi Rumah Kayu Di Tepian Sungai Kapuas. Langkau Betang; Jurnal Arsitektur Universitas Tanjungpura (LANTANG UNTAN), VOL 3 NO 2 (2016). Program Studi Arsitektur Universitas Tanjungpura. Pontianak

Manurung, Parmonangan. (2014). Arsitektur Berkelanjutan, Belajar Dari Kearifan Arsitektur Nusantara. Prosiding pada Simposium Nasional RAPI XIII - 2014 FT Universitas Muhammadiyah Surakarta A75-81. ISSN $1412-9612$
Mayasari, Maria Sicilia; Lintu Tulistyantoro; M Taufan Rizqy. (2014). Kajian Semiotik Ornamen Interior Pada Lamin Dayak Kenyah ( Studi Kasus Interior Lamin Di Desa Budaya Pampang). JURNAL INTRA Vol. 2, No. 2, (2014) 288-293

Rahmansah; Bakhrani Rauf. (2014). Arsitektur Tradisional Bugis Makassar (Survei Pada Atap Bangunan Kantor Di Kota Makassar). Jurnal Forum Bangunan : Volume 12 Nomor 2, Juli 2014

Suharjanto, Gatot. (2011). Membandingkan Istilah Arsitektur Tradisional Versus Arsitektur Vernakular: Studi Kasus Bangunan Minangkabau Dan Bangunan Bali. ComTech Vol.2 No. 2 Desember 2011: 592-602

Usop, Tari Budayanti. (2011). Kearifan Lokal Dalam Arsitektur Kalimantan Tengah Yang Berkesinambungan. Jurnal Perspektif Arsitektur Volume 6 Nomor 1 Juli 2011 